\title{
An evaluation methodology proposal for building envelopes containing phase change materials: the case of a flat roof in Turkey's climate zones
}

\author{
Ayça Tokuça , S. Cengiz Yesügey ${ }^{a}$ and Tahsin Başaran ${ }^{b}$

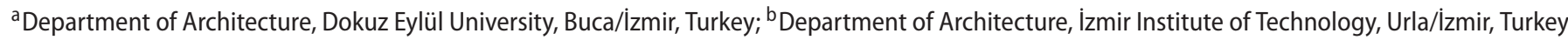

ABSTRACT

Phase change materials (PCMs) can be used to enhance the thermal energy storage capacity of a building element to improve indoor thermal comfort conditions and decrease energy usage, yet these effects need to be carefully analysed to achieve the desired benefits. This paper proposes an evaluation methodology for building envelopes: first, a numerical computational fluid dynamics model is validated by experimental work; then, time-dependent simulations are used to analyse monthly energy requirements and heat flux. A sample flat roof is evaluated in terms of required cooling load with and without PCM in Turkey's climate zones. Graphical phase change representations and heat flux results were used to evaluate the cooling load reduction in addition to the effects of PCM type and PCM amount and the necessity for night cooling. In conclusion, the methodology is flexible and can be utilized to evaluate the building element for various parameters.
ARTICLE HISTORY

Received 10 December 2016

Accepted 5 June 2017

\section{KEYWORDS}

Thermal mass; thermal energy storage; latent thermal energy storage; phase change material (PCM); cooling load

\section{Introduction}

Heating and cooling of buildings are usually the largest contributors to energy consumption in buildings today (Yang, Yan, and Lam 2014); therefore, discourses such as sustainability and low energy emphasize the necessity to use less energy for the future of the building industry. Although the intermittent nature of renewables has been a concern for their utilization - mainly for solar energy - many architectural technologies that incorporate the sun and other natural resources into the design of buildings have been developed since ancient times; one of these technologies is thermal mass (Hyde et al. 2009; Navarro et al. 2016).

Thermal mass is a passive building design strategy that is traditionally incorporated into the building by using materials with a high thermal energy storage capacity such as earth, stone and concrete, yet a contemporary alternative is materials incorporating PCMs. Sensible thermal energy storage in the traditional systems requires high density and specific heat thus have heavy construction, however, PCMs utilize latent thermal energy storage and have higher thermal energy storage capacities. Thus contemporary building elements with PCM would be lighter and thinner than traditional building elements. However, their utilization in buildings is not common and more research is necessary to understand their thermal behaviour and other properties.

The aim of this paper is twofold. First aim is to create a methodology that can be used to provide guidance to the designers for PCM implementation and detailing. Second is a case showing its applicability on a research question of a building element in different climate zones. The selected question specifically deals with a flat roof in Turkey's climate zones, which are relevant for various parts of the world, especially temperate climate zones. The evaluation methodology would help the designer to configure and detail building elements containing PCM in the building design stage. Experimental validation of the simulation was widely discussed, and a suitable PCM thickness was found for a flat roof application in İstanbul (Tokuç 2013; Tokuç, Başaran, and Yesügey 2015a). In addition, the experimental data are shared in Tokuç, Başaran, and Yesügey (2015b). The current study builds upon these studies and focuses on defining a method for evaluating cooling load effects under different climatic conditions. The suggested methodology incorporates an interpretation of graphical representations and calculations via simulation: first, the simulation is experimentally validated; then, the method is applied to four different climate conditions representing the four climate zones in Turkey, and the use of differing amounts of PCM in different climate zones is compared. Thus, the suitability of the methodology for different climate zones is evaluated, and the zones are compared according to different considerations.

\section{Literature review}

Under steady-state conditions, two building elements having the same thermal transmittance would have identical heat flow, however, the thermal energy storage capacity of a material, usually referred as thermal mass, affects the behaviour of the element. High thermal mass shifts the time of the interior peak load, called time-lag, and decreases the amplitude of the peak from the daily average by a factor called as the decrement factor (Szokolay 2004). The prominent design parameters for thermal mass incorporation include the amount (Slee, Parkinson, and Hyde 2014) and distribution of mass (Mithraratne and Vale 2006). 
Ghoreishi and Ali (2013) studied many parameters regarding the thermal mass of concrete buildings in the United States' climate zones and found that while the addition of thermal mass generally reduces heating, cooling and total energy consumption regardless of location, extreme climate conditions show higher efficiency. Başaran (2011) experimentally showed the importance of thermal mass effects in Harran vernacular houses to reach relatively stable indoor thermal environment under extreme summer conditions. However, parameters of the occupancy schedule, wall thickness and window/wall ratio, in accordance with the orientation of the building envelopes, need to be carefully considered for application due to their sensitivity levels (Senel Solmaz, Halicioglu, and Gunhan 2016).

One of the ways to increase thermal mass of the buildings is by incorporating phase change materials (PCMs) in building elements. There is a growing body of literature on PCMs in building applications, and Kalnæs and Jelle (2015) and Soares et al. (2013) provide a state of the art review of PCMs and PCMincorporated products, while Akeiber et al. (2016) and Souayfane, Fardoun, and Biwole (2016) focus on cooling applications. The solidification and internal/external melting periods of PCM were studied experimentally by Ezan and Erek (2012), in accordance with numerical investigation by Ezan, Erek, and Dincer (2011)

There are various applications of PCM incorporation into building elements; however, since the thermal energy flow between indoors and outdoors takes place through the building envelope, this study focuses on a roof element, with its cooling potential to reduce downward heat flux. Liu et al. (2016) numerically considered filling double-glazed roofs with PCM and studied the parameters of temperature time-lag, total transmitted energy and transmitted solar energy for different time periods and different PCM thicknesses. Alqallaf and Alawadhi (2013) numerically studied a concrete roof with vertical cone holes filled with PCM in terms of heat flux and found reductions, depending on the operating month and working hours. Li et al. (2015) numerically studied the performance of five different roofs and found that PCM roofs delay peak temperatures compared to a normal roof. Lu et al. (2016) performed a field test for three rooms and found that the PCM roof shows good effects on decreasing the peaks of temperature and heat flux while showing better thermal insulation and thermal inertia performance with the addition of cool cover.

There are many issues to consider for a successful application, including advantages and disadvantages of PCM types, their thermal energy storage capacities, thermophysical properties and melting/freezing temperatures, their relation to the outside and comfort temperatures, and their careful detailing for building integration (Jin et al. 2014). However, one of the most significant limitations of PCM products becoming more common in the building market is the necessity for load calculation and simulation according to the building and climate to identify the necessary amount of PCM. This paper proposes a methodology to consider these parameters, and an example case is given below.

\section{The problem description}

This case investigates the incorporation of a layer of PCM into a classic flat roof element, and its latent thermal energy effect on decreasing the cooling energy load is investigated in the cases of climate zones of Turkey, which is currently divided into four climate zones according to Turkish Standard TS-825 (Turkish Standards Institute 2008). The cases are evaluated parametrically for differing PCM thicknesses. The data from a validated simulation model are used to calculate the energy that can be saved by utilizing PCMs, and the ratio is relative to the total cooling energy. Some parameters related to practical applications, such as architectural detailing and life cycle costs, are beyond the scope of this paper.

\subsection{The roof detail}

A flat roof element, detailed according to Turkish Standards, is selected for the PCM application. The selected roof section, from top to bottom, consists of white ceramic and binding mor$\operatorname{tar}(1.5 \mathrm{~cm}$ altogether), levelling concrete $(5 \mathrm{~cm})$, three layers of waterproofing membrane ( $1 \mathrm{~cm}$ altogether), PCM inside a metal box $(5 \mathrm{~cm})$, thermal insulation $(6 \mathrm{~cm})$ and reinforced concrete $(10 \mathrm{~cm})$.

\subsection{PCM selection}

The building type in this study is selected as a dwelling since a dwelling is used 24 hours a day and must meet thermal comfort conditions throughout the night. Kauranen, Peippo, and Lund (1991) suggest an ideal phase change temperature of $1-3^{\circ} \mathrm{C}$ above normal room temperature for passive solar applications with direct thermal gains and short-term thermal energy storage. If the room comfort temperature is taken as $25^{\circ} \mathrm{C}$ for cooling purposes in summer, then the phase change temperature of the PCM can be taken as $26-28^{\circ} \mathrm{C}$. Moreover, phase change stability, safety and preventing chemical reactions with other building elements were other important criteria for PCM selection; thus, Rubitherm ${ }^{\circledR}$ RT27 was selected (Tokuç 2013). The thickness of the PCM was taken as $5 \mathrm{~cm}$ to provide meaningful results from the experimental work.

\subsection{Experimental work}

The numerical model was validated with the experimental results. For the experiment, a $50 \mathrm{~cm}$ by $50 \mathrm{~cm}$ roof area section was constructed at a $1 / 1$ scale to show the thermophysical properties of a real roof. The experimental setup is given in Figure 1 and consists of (i) insulated box, (ii) flowmeter with insulated pipes for fluid transportation, (iii) constant temperature baths, (iv) resistant temperature detectors, PT-100 and (v) building element and the observation system consisting of a datalogger, a camera and a desktop computer.

The roof section, numbered (v) in Figure 1, is inserted into a wooden box and is insulated with $15 \mathrm{~cm}$ extruded polystyrene as (i) in Figure 1. Thermal conditions that a roof would face in reality are applied to its upper and lower surfaces via fluid transportation systems, and their volumetric rates are measured by flowmeters ((ii) in Figure 1). The fluids are conditioned for upper and lower surfaces of the building element by two constant temperature baths, as shown by (iii) in Figure 1, and are pumped through copper serpentines placed above and below the surfaces of the roof so that the temperatures of the upper and lower surfaces can be stabilized at desired temperatures. Through this 


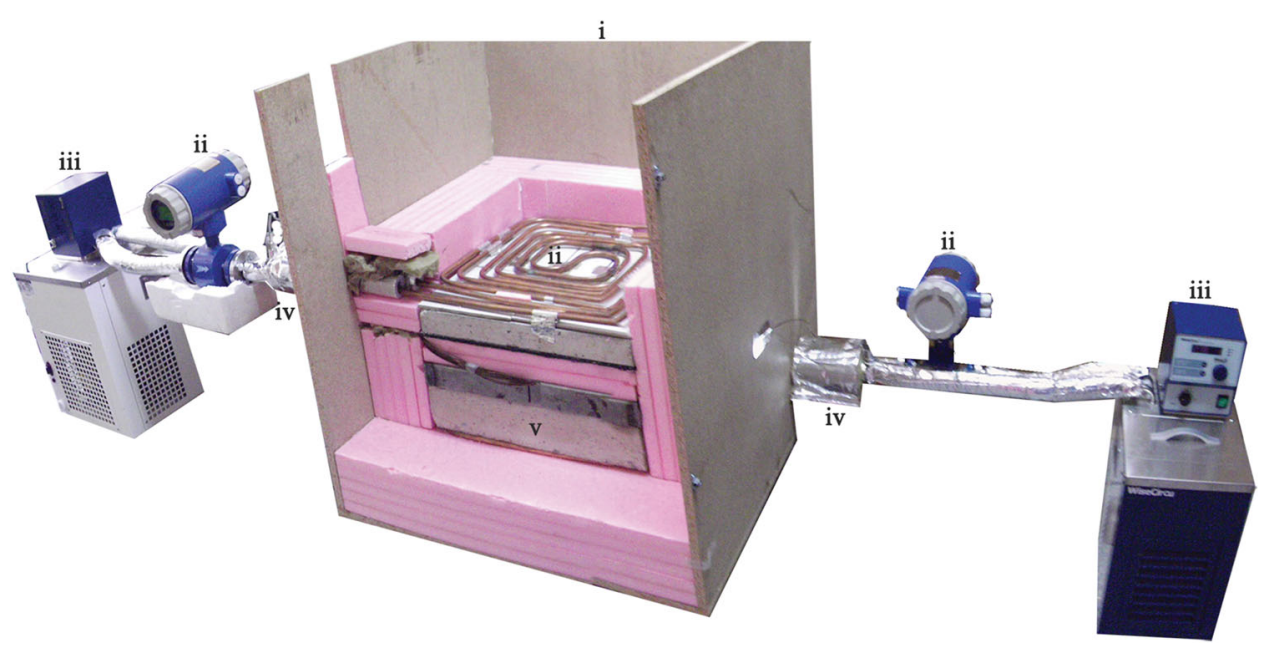

Figure 1. The experimental setup: (i) insulated box, (ii) flowmeters with insulated pipes for fluid transportation, (iii) constant temperature baths, (iv) resistant temperature detectors, PT-100 and (v) building element.

system, the PCM inside the roof can be melted and solidified, and the thermal behaviour of the PCM can be observed. The temperatures of the fluids that circulate inside the setup at the upper and lower surfaces are measured by resistant temperature detectors, PT-100, given as (iv) in Figure 1.

T-type thermocouples are used to measure the temperatures inside and around the setup. A total of 13 thermocouples are located on/inside the roof element. The temperature values regarding the melting and solidification cycles are taken from 11 thermocouples placed at $5 \mathrm{~mm}$ intervals inside the PCM layer. The temperatures of the upper, side and lower surface temperatures, as well as high, middle and low temperatures of the laboratory, were also measured. In addition, the phase change is observed by a camera through an opening on the side of the PCM-containing box. All of the data recorded by the datalogger and the camera are transferred to the computer.

The experiments involved the setting of the lower surface of the roof element, which represents the roof of a room conditioned at $25^{\circ} \mathrm{C}$, and the upper surface of the roof at a temperature that represents summer outdoor conditions; then, the melting and energy balance of the PCM were observed. Figure 2 shows the temperature change inside the roof during 72 hours of two experiments when the upper surface temperature is $60^{\circ} \mathrm{C}$, thus the thermal inertia effect of PCM inside the element was shown. Furthermore, the replicability and reproducibility of the experiments were calculated via a second experiment. In other experiments, the upper surface temperatures were set at $40^{\circ} \mathrm{C}$ and $50^{\circ} \mathrm{C}$. At the beginning of the experiments, all of the temperatures inside the roof element were $25^{\circ} \mathrm{C}$, and the PCM was solid; meanwhile, the laboratory temperature was also set at a constant $25^{\circ} \mathrm{C}$ to minimize heat loss. Before the experiments were realized, experiments on the roof element were carried out without the PCM layer to check for energy balance.

\subsection{Simulation validation}

To solve phase change problems and energy flow inside a building element analytically is a very complex and time-consuming application, and limited analytical solutions have been obtained. Therefore, various numerical methods and algorithms that can

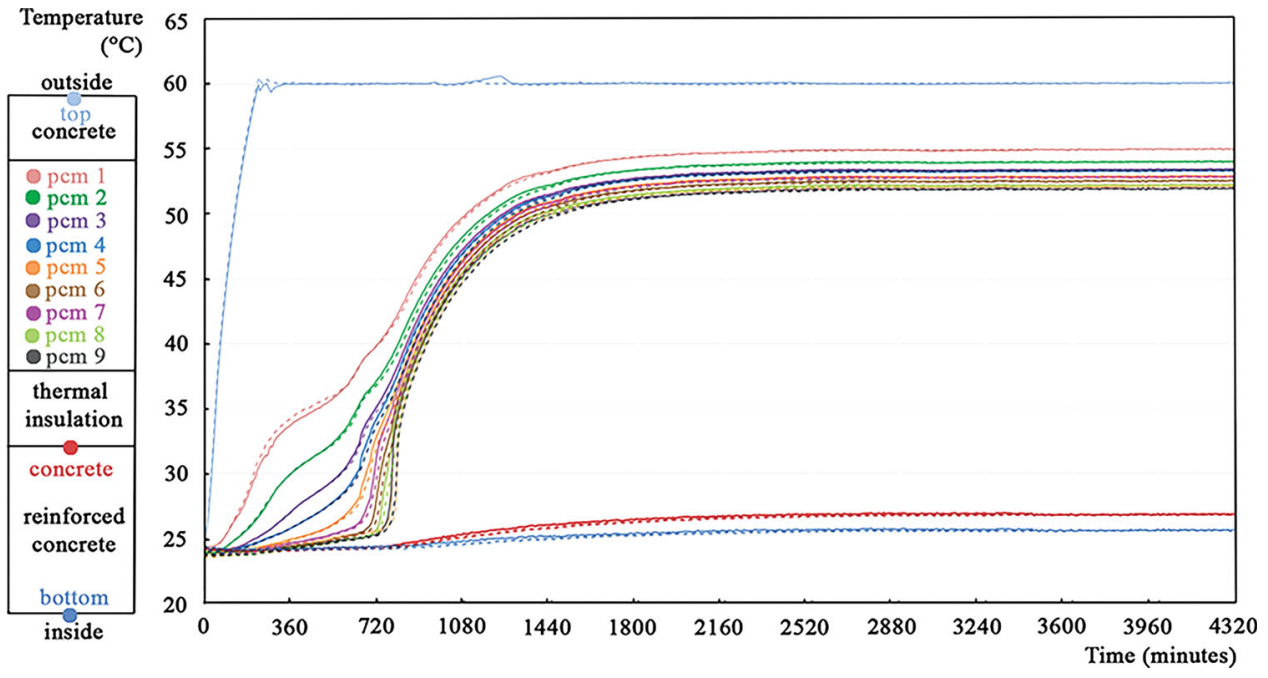

Figure 2. Data from the experiments, $60^{\circ} \mathrm{C}$ upper surface temperature. 
solve these types of problems are generated on a problem basis. In a computational fluid dynamics (CFD) environment, a problem is defined by applicable boundary conditions and modelled by computers allowing for more rapid and precise solutions (Chung 2002; Versteeg and Malalasekera 2007).

In this study, the model is applied to a building element that is air conditioned on the one side and has outside conditions on the other side. Therefore, assumptions to simplify the model are as follows: there is only one-dimensional heat transfer in the element, and the PCM transfers energy only by transmission, in other words, not by other means such as natural convection. Materials have constant thermophysical properties, except for the PCM during phase change, where the specific heat changes. Since the melting and solidification temperature of the PCM are not exactly constant but occur over a relatively small temperature range; the phase change temperature

Table 1. Thermophysical properties of all materials in the simulation.

\begin{tabular}{lccc}
\hline $\begin{array}{l}\text { Material or } \\
\text { element type }\end{array}$ & $\begin{array}{c}\text { Mass per unit } \\
\text { volume }\left(\mathrm{kg} / \mathrm{m}^{3}\right)\end{array}$ & $\begin{array}{c}\text { Thermal } \\
\text { conductivity } \\
(\mathrm{W} / \mathrm{mK})\end{array}$ & $\begin{array}{c}\text { Specific heat } \\
(\mathrm{kJ} / \mathrm{kgK})\end{array}$ \\
\hline $\begin{array}{l}\text { Ceramic (and } \\
\text { binding mortar) }\end{array}$ & 1750 & 1.45 & 0.879 \\
$\begin{array}{l}\text { Concrete } \\
\text { Water insulation }\end{array}$ & 2200 & 1.1 & 0.85 \\
$\begin{array}{l}\text { (3 layers) } \\
\text { Selected PCM }\end{array}$ & 1200 & 0.19 & 0.92 \\
$\begin{array}{l}\text { XPS board (2 layers) } \\
\text { Reinforced }\end{array}$ & 760 & 0.2 & 2.40 \\
concrete & 2400 & 0.035 & $280.40^{\mathrm{a}}$ \\
\hline
\end{tabular}

${ }^{\text {a }}$ During phase change - between $25.72^{\circ} \mathrm{C}$ and $26.22^{\circ} \mathrm{C}$. range is assumed to be $0.5^{\circ} \mathrm{C}$, between $25.72^{\circ} \mathrm{C}$ and $26.22^{\circ} \mathrm{C}$ (Tokuç, Başaran, and Yesügey 2015a). During the phase change, both sensible and latent heat are stored in the PCM; therefore, $280.4 \mathrm{~kJ} / \mathrm{kgK}$ of $c_{p}$ is defined for the PCM at the phase change temperature range in the CFD code. The thermophysical properties of all the materials (except PCM) in the simulation were experimentally measured and given in Table 1 . The properties of composite materials; 'Ceramic (and binding mortar)', and 'Reinforced concrete' were given as weighted average (the data for constructional steel were taken from (Cengel 2007). The properties for PCM were taken from Sheth Karathia (2011).

FLUENT $^{\circledR}$ software was used for the simulation. First, the geometry and mesh were generated with the help of the Geometry \& Mesh Building Intelligent Toolkit (GAMBIT). Then, the volumes were defined as solid or liquid, the boundary conditions were defined as 'wall', and the geometry was transformed into a two-dimensional mesh. The roof section geometry was defined as having a $10 \mathrm{~cm}$ width to ensure rapid calculation. Three different mesh configurations were considered before selecting the size of the mesh elements. The selected mesh size that gives accurate results at the acceptable running time is $0.5 \mathrm{~cm}$ by $0.2 \mathrm{~cm}$ in the PCM layer and $0.5 \mathrm{~cm}$ by $0.5 \mathrm{~cm}$ in the remaining materials (Tokuç 2013).

FLUENT $^{\circledR}$ calculates by using the finite volume analysis method, in which the defined geometry is divided into control volumes, and equations that represent each control volume are solved (Ansys Inc. 2009). At first, the equations that define heat flow are integrated into the mesh, and integral equations are later transformed into algebraic equations, which are solved iteratively. According to the assumptions above, only the energy

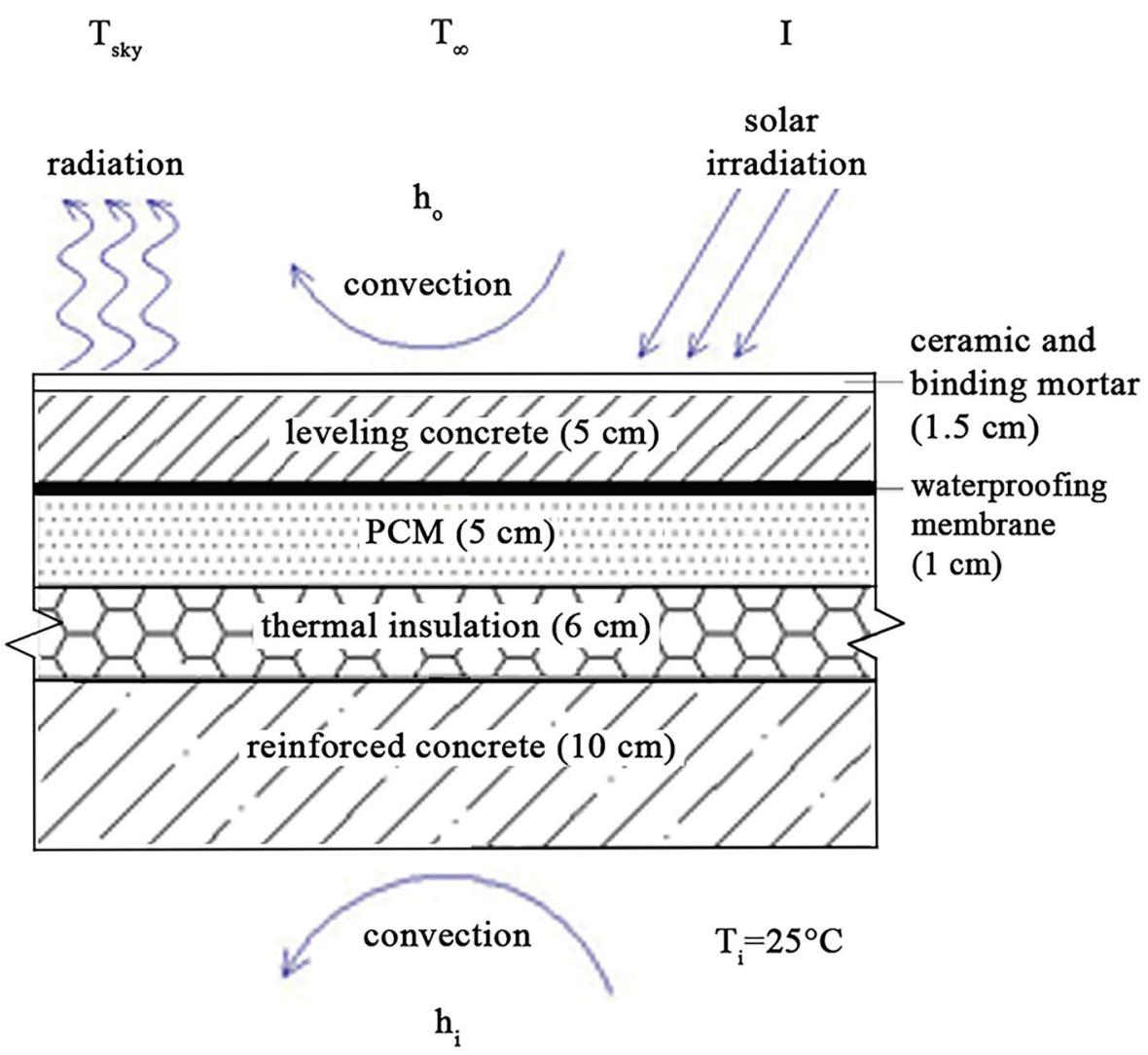

Figure 3. Boundary conditions for the simulation (adapted from Tokuç, Başaran, and Yesügey 2015a). 
equation is solved for this problem. Three different time steps were considered before selecting the time step, and $300 \mathrm{~s}$ was selected as a suitable time step for the unsteady analysis (Tokuç 2013). When the numerical results for experiment and simulation are compared for cases with and without PCM, the temperature differences between the experimental measurements and the numerical results changed between $0.28 \%$ and $5.30 \%$, which is an acceptable fit for the purpose of this study (Tokuç, Başaran, and Yesügey 2015a).

\subsection{Boundary conditions for the simulation}

To reach meaningful results by simulation, the boundary conditions play a crucial role in the correct identification of the problem. Since the indoor environment is conditioned, it is assumed to be kept at a constant temperature of $25^{\circ} \mathrm{C}$; thus, only heat convection is defined for the lower surface of the model, and thermal radiation is omitted. There is heat conduction inside the roof elements. In addition, heat convection, sky and solar radiations are considered for the outdoor surface conditions. The boundary conditions of the numerical model are given in Figure 3.

\section{Methods}

While the scope of this paper includes the effect of PCM under different climate conditions for five months that require cooling loads, this paper makes use of a graphical visualization of PCM melting-freezing interface and heat flux transmission on the lower surface of the roof. These tools make the data more comprehensible since PCM interfaces show the effectiveness of PCM through time, and the active thickness during the heat flux indicates its effect on energy consumption.

\subsection{Graphical visualization}

The visualization tool shows the melting-freezing cycle of PCM in the roof element graphically. To show the reading and evaluation of these graphs, one day in İzmir is simulated and visualized for different PCM thicknesses from 1 to $5 \mathrm{~cm}$ in $2 \mathrm{~cm}$ increments. The selected date is the 17th of June, a typical day for June according to Duffie and Beckman (1991), and is processed by Matlab ${ }^{\circledR}$ R2012a (The MathWorks Inc., Natick, MA, USA) software. Climate data are averaged from 10 years of meteorological station data between 2000 and 2010 from the Turkish State Meteorological Service (2012). The simulation was run for three days before the 17th of June to generate a realistic initializing temperature distribution through the element. Figure 4 is a section that shows the temperature distribution inside the roof element for 24 hours. The vertical axis in the figure indicates the positioning of the building materials inside the roof, and the horizontal axis denotes 24 hours from 0:00 to 24:00. The legend is the coloured bar and shows temperatures (ranging between $21.6^{\circ} \mathrm{C}$ and $36^{\circ} \mathrm{C}$ ), with red indicating hotter temperatures and blue indicating cooler temperatures (Tokuç, Başaran, and Yesügey 2015c).

[If viewed in greyscale, the higher temperatures are in the top central regions, and the lower temperatures are in the upper corners, and the lower half.]
Figure 4 first shows the temperature distribution for all the building elements in a flat roof with no added PCM; in other words, with only sensible thermal energy storage. Later, the thermal inertia effect of adding 1,3 and $5 \mathrm{~cm}$ PCM is shown. The peak temperatures in the legend $\left(21.6^{\circ} \mathrm{C}\right.$ and $36^{\circ} \mathrm{C}$ ) are observed on surfaces of the roof without PCM. The peak temperatures of the roofs with a PCM layer inside show a temperature distribution range from $22.4^{\circ} \mathrm{C}$ to $34.3^{\circ} \mathrm{C}$; thus, the incorporation of PCM has shown the time-lag and the capability to decrease the temperature of the building element.

All building elements show a decrease in temperature from midnight till sunrise at approximately 06:00 because of the effect of the outside temperature and the thermal radiation to the night sky. Therefore, the heat energy stored in the element during the previous day is sent outdoors. The minimum surface temperatures of the roofs are reached at the end of this period, just before sunrise. Meanwhile, the solidification of the PCM also takes place during this time period.

Between 06:00 and 14:00 hours, the solar insolation coming to the surface of the roof is the major thermal contributor; however, heat convection also contributes to thermal load. The
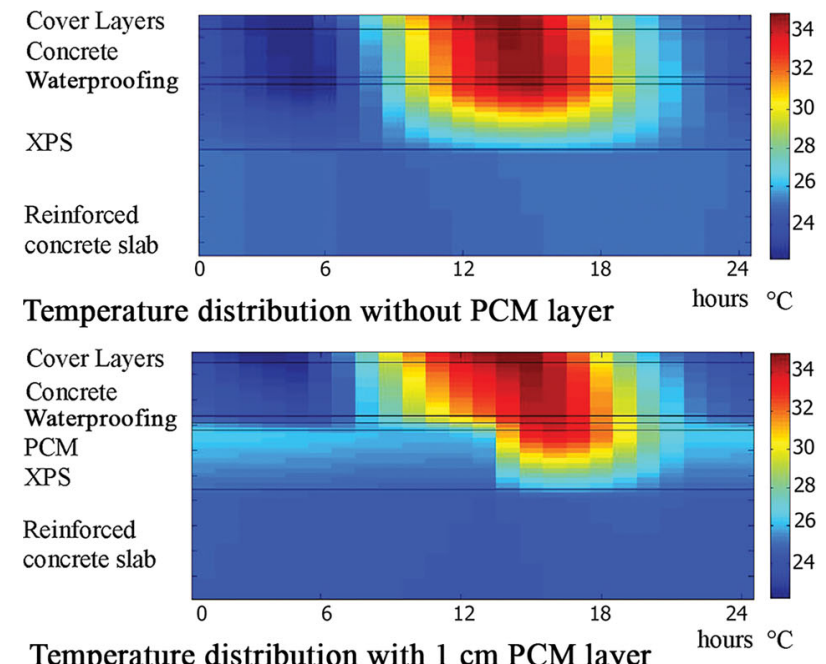

Temperature distribution with $1 \mathrm{~cm}$ PCM layer

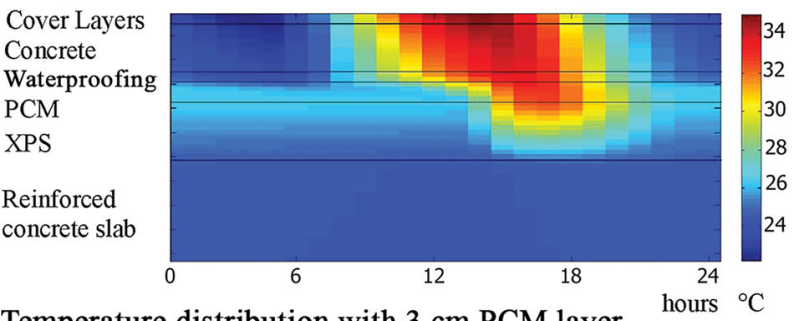

Temperature distribution with $3 \mathrm{~cm}$ PCM layer

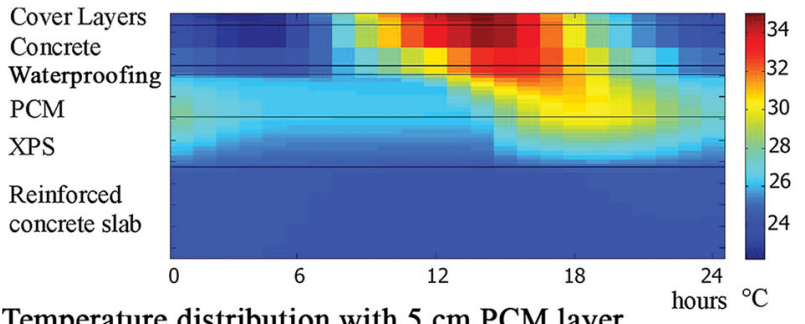

Temperature distribution with $5 \mathrm{~cm}$ PCM layer

Figure 4. The temperature distribution inside a flat roof with and without PCM layer for 17 th of June in Izmir. 
solar insolation continuously rises, and the temperatures inside the element also continue to rise accordingly. At approximately $16: 00$, the highest surface temperature is observed. In this timeframe, the PCM melts and impedes the conduction of heat to the thermal insulation layer below. This time-lag effect due to PCM is observed.

Although the sun stays on the horizon and gives off radiation until 20:00, after 16:00, the convective heat loss to the outdoors is more dominant than the incoming solar radiation; therefore, the surface temperature begins to decrease. The rate of heat loss increases after sundown. As the PCM thickness in the roof detail - thus the amount of PCM - increases, so does the thermal energy stored in the mornings; thus the dissipation of heat to the outdoors takes longer. Consequently, if enough heat to ensure solidification is not released, the thermal behaviour of the element on the following day shows more similarities to the elements with only sensible thermal energy storage.

Figure 5 visualizes the amount of phase change for a comparative evaluation of the PCM for the whole month of May in
İzmir for $1-5 \mathrm{~cm}$ PCM thickness in $1 \mathrm{~cm}$ increments. The black and white denote the solid and liquid phases of the PCM, respectively, therefore it is possible to observe whether the PCM is solid or liquid and to what degree for any day during May. For $1 \mathrm{~cm}$ PCM thickness, the melting-solidification cycle occurs for the whole PCM thickness from the start till the end of the month. However, for the $3 \mathrm{~cm}$ PCM thickness, the solidification does not wholly occur in the PCM in the latter half of the month. The case of $5 \mathrm{~cm}$ PCM thickness shows a similar trend to all the other graphs with PCM. After the 18th of the month, only the top $2 \mathrm{~cm}$ of the PCM constantly melts and solidifies, and the remaining lower PCM thickness mainly remains in a liquid phase. Therefore, the behaviour of PCM can be inferred by analysing the behaviour of the $5 \mathrm{~cm}$ thick PCM; thus, through the rest of this paper, the visualizations are given in greyscale for a whole month for $5 \mathrm{~cm}$ PCM and this figure provides reference for interpretation of further figures. More detail on the PCM behaviour for different thicknesses can be found in Tokuç (2013).

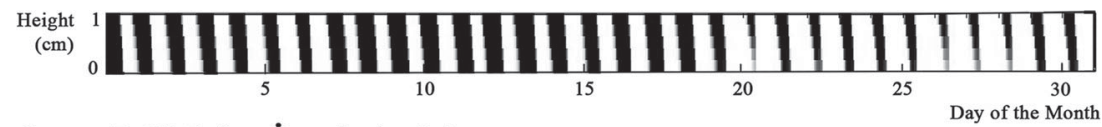

$1 \mathrm{~cm}$ PCM for İzmir in May

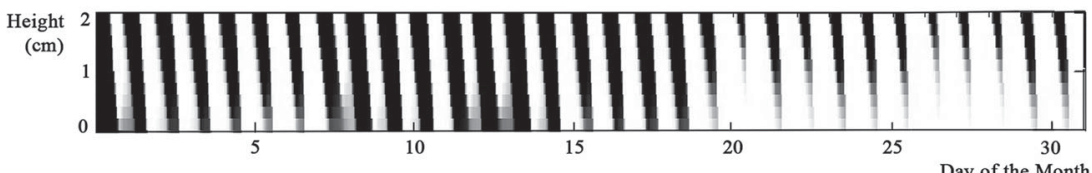

$2 \mathrm{~cm}$ PCM for İzmir in May

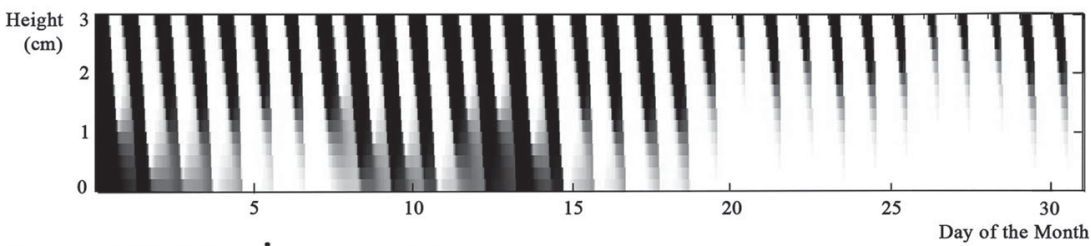

$3 \mathrm{~cm}$ PCM for İzmir in May

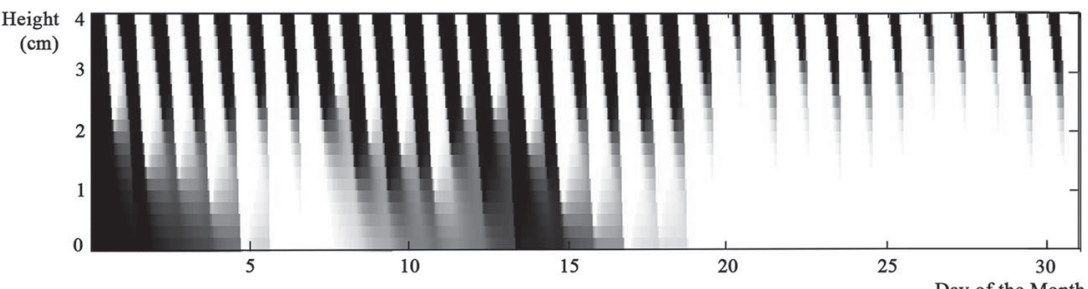

$4 \mathrm{~cm}$ PCM for Izmir in May

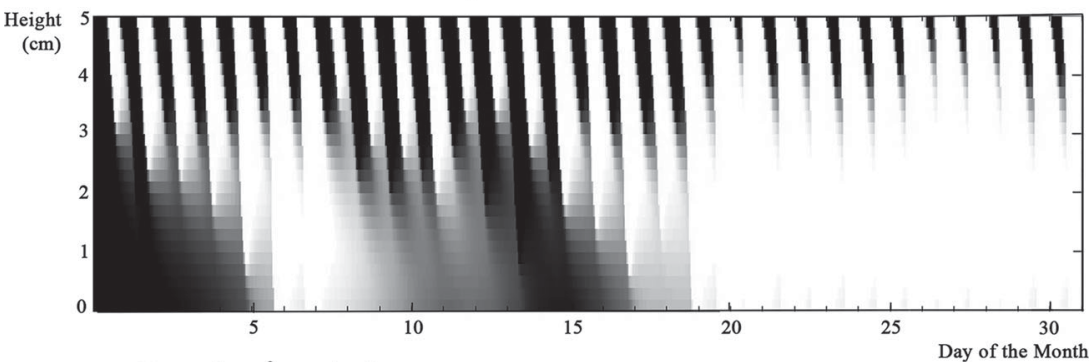

$5 \mathrm{~cm}$ PCM for İzmir in May

Figure 5. Solid-liquid* states of PCM for İzmir in May (*black denotes solid and white denotes liquid state). 


\subsection{Heat flux calculation}

The utilization of PCM changes according to the properties and thickness of the PCM layer in addition to the heat balance on the slab's surface due to both the properties of the roof materials (such as thermal absorption, emissivity, density, specific heat and thermal conductivity), and time-dependent weather data (such as solar irradiation, ambient temperature, sky temperature, wind speed and relative humidity). The total heat energy flow rate through the roof element is also dependent on these elements and is given by heat flux calculation. In addition, the amount of energy necessary to cool down $1 \mathrm{~m}^{2}$ of a room with the simulated roof element is related to the energy entering the interior through the roof. Therefore the heat flow is given in terms of total energy coming through a unit area $\left(\mathrm{Wh} / \mathrm{m}^{2}\right)$ and the energy entering through different roof configurations is compared according to Equation (1),

$$
\left(\left(q_{\text {noPCM }}-q_{P C M}\right) / q_{\text {noPCM }}\right) \times 100=\% \text { Performance }
$$

In this equation, $q_{\text {noPCM }}$ gives the amount of energy per unit area $\left(\mathrm{Wh} / \mathrm{m}^{2}\right)$ that passes through a roof without any PCM incorporation, while $q_{P C M}$ is the amount of energy per unit area $\left(\mathrm{Wh} / \mathrm{m}^{2}\right)$ that passes through a roof with PCM incorporated, and \%Performance denotes the performance of the building element in decreasing the cooling load (\%).

\section{Simulation results for different climates}

Turkey is divided into four climatic zones according to the Turkish Standard TS-825 Rules for Heat Insulation in Buildings (Turkish Standards Institute 2008), and while these zones are primarily used to calculate the heating load of buildings, there is no other standard for cooling requirements; therefore, these four zones are evaluated in this study. The evaluation uses results from simulations for cities that represent these climate zones; Izmir for the 1st zone, İstanbul for the 2nd zone, Ankara for the 3rd zone and Erzurum for the 4th zone, as shown in Figure 6 . Since the changes in the climate zones require the utilization of different roof details, the insulation thicknesses for the four zones

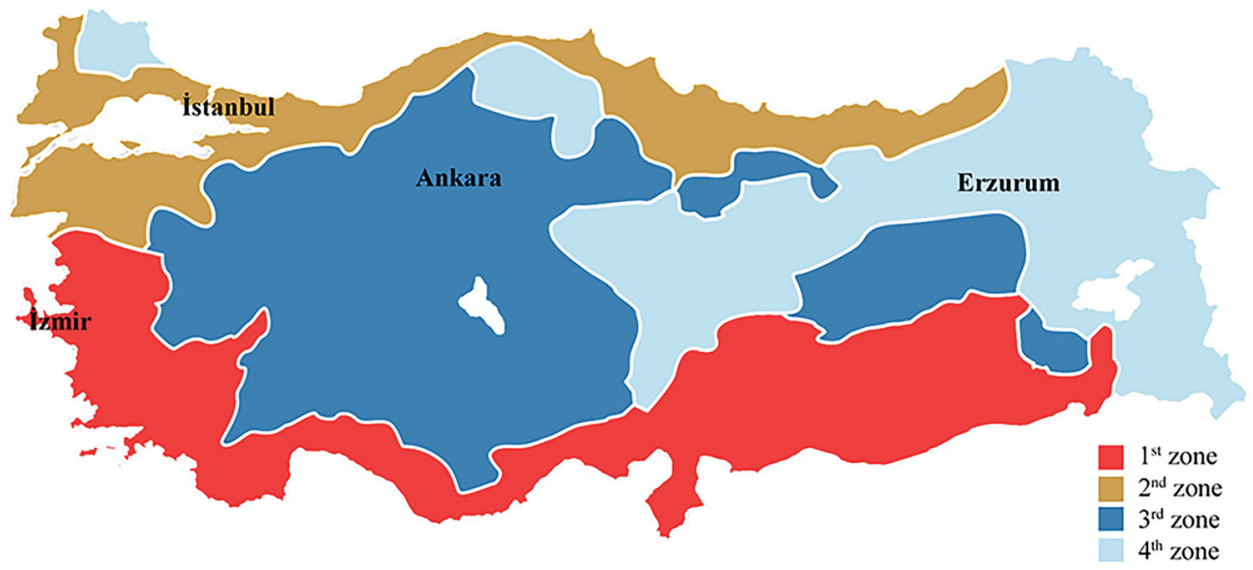

Figure 6. Climate zones in Turkey and representative cities.

Table 2. Climatic conditions of selected cities in different climate regions of Turkey (Turkish Standards Institute 2008; Turkish State Meteorological Service 2017).

\begin{tabular}{|c|c|c|c|c|c|}
\hline Region City & Latitude, Longitude & Trewartha & Thornthwaite & HDD & CDD \\
\hline 1st Region İzmir & $38^{\circ} 43^{\prime} \mathrm{N}, 27^{\circ} 17^{\prime} \mathrm{E}$ & Cool winters Hot summers & C1 Semi-arid, low humidity B3 Mesothermal & 985 & 660 \\
\hline 2nd Region İstanbul & $40^{\circ} 97^{\prime} \mathrm{N}, 29^{\circ} 08^{\prime} \mathrm{E}$ & Cool winters Warm summers & B1 Humid B2 Mesothermal & 1690 & 215 \\
\hline 3rd Region Ankara & $39^{\circ} 95^{\prime} \mathrm{N}, 32^{\circ} 88^{\prime} \mathrm{E}$ & Cold winters Hot summers & D Semi-arid B1 Mesothermal & 2393 & 251 \\
\hline 4th Region Erzurum & $39^{\circ} 95^{\prime} \mathrm{N}, 41^{\circ} 17^{\prime} \mathrm{E}$ & Cold winters Mild summers & C1 Semi-arid, low humidity C2 Microthermal & 4425 & 16 \\
\hline
\end{tabular}

Table 3. Monthly climate data for selected cities in different climate regions of Turkey (Turkish Standards Institute 2008; Meteonorm 2012).

\begin{tabular}{|c|c|c|c|c|c|c|c|c|c|c|c|c|c|}
\hline Region City & Parameters & Jan & Feb & Mar & Apr & May & Jun & Jul & Aug & Sep & Oct & Nov & Dec \\
\hline \multirow[t]{3}{*}{ 1st Region İzmir } & $\operatorname{Avg} T_{\text {monthly }}\left({ }^{\circ} \mathrm{C}\right)$ & 6.8 & 8.1 & 11.9 & 15.8 & 21.2 & 26.4 & 28.4 & 27.7 & 22.5 & 18.0 & 12.5 & 8.2 \\
\hline & $\operatorname{Avg}\left(T_{\max }-T_{\min }\right)\left({ }^{\circ} \mathrm{C}\right)$ & 6.7 & 7.4 & 8.6 & 9.7 & 10.7 & 11 & 10.7 & 10.7 & 10.5 & 9.4 & 7.9 & 6.5 \\
\hline & $I_{\text {solar }}\left(\mathrm{kWh} / \mathrm{m}^{2}\right)$ & 107 & 124 & 162 & 247 & 297 & 320 & 340 & 295 & 221 & 155 & 121 & 99 \\
\hline \multirow[t]{3}{*}{ 2nd Region İstanbul } & Avg $T_{\text {monthly }}\left({ }^{\circ} \mathrm{C}\right)$ & 6.2 & 6.4 & 8.9 & 12.5 & 17.7 & 22.7 & 25.5 & 25.5 & 21.2 & 17.1 & 12.1 & 8.2 \\
\hline & $\operatorname{Avg}\left(T_{\max }-T_{\min }\right)\left({ }^{\circ} \mathrm{C}\right)$ & 5.3 & 5.9 & 6.7 & 7.8 & 7.9 & 8.1 & 7.1 & 6.7 & 6.9 & 6.2 & 5.9 & 5.3 \\
\hline & $I_{\text {solar }}\left(\mathrm{kWh} / \mathrm{m}^{2}\right)$ & 60 & 85 & 138 & 206 & 262 & 290 & 284 & 249 & 183 & 117 & 79 & 54 \\
\hline \multirow[t]{3}{*}{ 3rd Region Ankara } & Avg $T_{\text {monthly }}\left({ }^{\circ} \mathrm{C}\right)$ & -1.1 & 0.9 & 5.8 & 10.5 & 15.5 & 19.9 & 23.6 & 23.6 & 18.0 & 12.5 & 5.8 & 0.8 \\
\hline & $\operatorname{Avg}\left(T_{\max }-T_{\min }\right)\left({ }^{\circ} \mathrm{C}\right)$ & 7.5 & 9.6 & 13.8 & 16.7 & 17 & 17 & 17.4 & 14.6 & 10 & 8.2 & 6 & 4 \\
\hline & $I_{\text {solar }}\left(\mathrm{kWh} / \mathrm{m}^{2}\right)$ & 69 & 98 & 131 & 194 & 220 & 267 & 271 & 237 & 176 & 120 & 91 & 74 \\
\hline \multirow[t]{3}{*}{ 4th Region Erzurum } & Avg $T_{\text {monthly }}\left({ }^{\circ} \mathrm{C}\right)$ & -12.3 & -8.8 & -1.4 & 5.3 & 10.1 & 14.5 & 18.8 & 19.3 & 14.0 & 8.0 & 0.1 & -7.9 \\
\hline & $\operatorname{Avg}\left(T_{\max }-T_{\min }\right)\left({ }^{\circ} \mathrm{C}\right)$ & 9.9 & 10.2 & 9.6 & 10.8 & 12.4 & 14.3 & 15.2 & 15.9 & 16.1 & 13.3 & 10.4 & 9.2 \\
\hline & $I_{\text {solar }}\left(\mathrm{kWh} / \mathrm{m}^{2}\right)$ & 93 & 131 & 187 & 206 & 222 & 269 & 268 & 239 & 210 & 139 & 89 & 80 \\
\hline
\end{tabular}


are changed for a healthier comparison. True meteorological year (TMY-2) climate data are taken from the Meteonorm v.7 database, based on 20 years of climatic measurements for the selected cities (Remund and Müller 2011), is used for the simulations. The position and a summary of climate conditions of the selected cities are given in Table 2 (heating degree days (HDD)

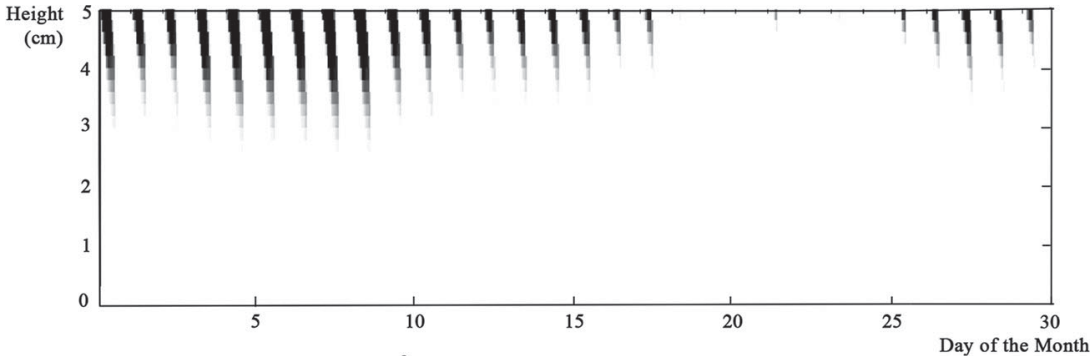

$5 \mathrm{~cm}$ PCM for June in İzmir

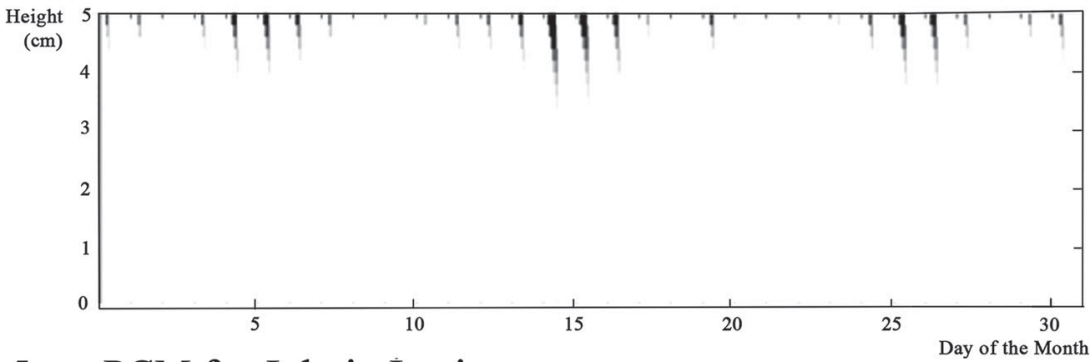

$5 \mathrm{~cm}$ PCM for July in İzmir

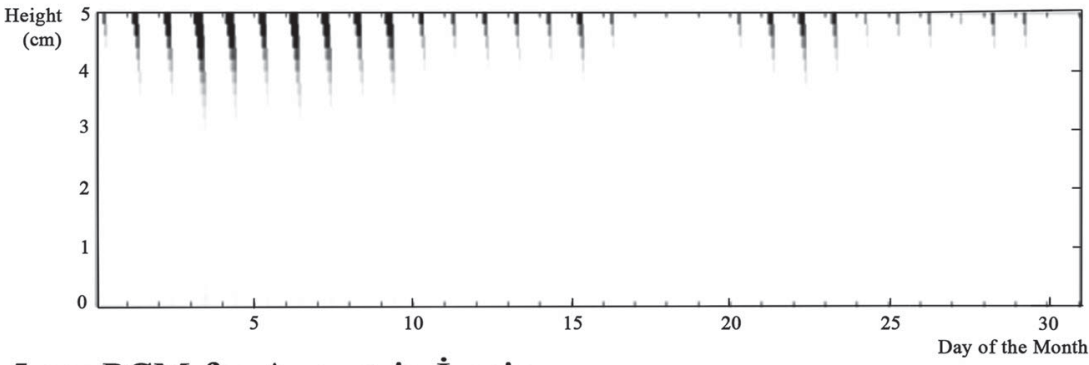

$5 \mathrm{~cm}$ PCM for August in İzmir

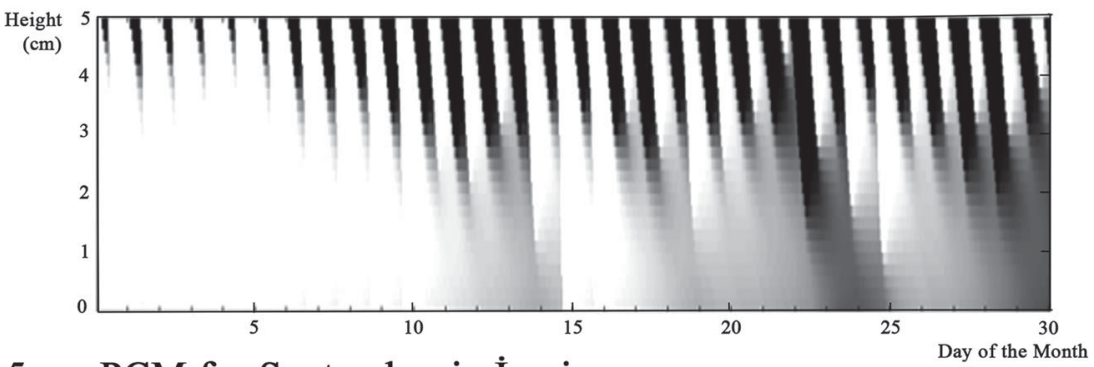

$5 \mathrm{~cm}$ PCM for September in İzmir

Figure 7. Solid-liquid* states of PCM between June and September in İmir (*black denotes solid and white denotes liquid state).

Table 4. Monthly and daily average cooling energy requirement in Izmir $\left(\mathrm{Wh} / \mathrm{m}^{2}\right)$.

\begin{tabular}{|c|c|c|c|c|c|c|c|}
\hline & & No PCM & $\begin{array}{l}1 \mathrm{~cm} \\
\text { PCM }\end{array}$ & $\begin{array}{l}2 \mathrm{~cm} \\
\text { PCM }\end{array}$ & $\begin{array}{l}3 \mathrm{~cm} \\
\text { PCM }\end{array}$ & $\begin{array}{l}4 \mathrm{~cm} \\
\text { PCM }\end{array}$ & $\begin{array}{l}5 \mathrm{~cm} \\
\text { PCM }\end{array}$ \\
\hline \multirow[t]{2}{*}{ May } & Monthly & 489.7 & 444.0 & 403.9 & 355.6 & 300.9 & 253.7 \\
\hline & Daily & 15.8 & 14.3 & 13.0 & 11.5 & 9.7 & 8.2 \\
\hline \multirow[t]{2}{*}{ June } & Monthly & 2766.4 & 2675.4 & 2582.9 & 2486.1 & 2405.6 & 2337.5 \\
\hline & Daily & 92.2 & 89.2 & 86.1 & 82.9 & 80.2 & 77.9 \\
\hline \multirow[t]{2}{*}{ July } & Monthly & 4052.4 & 3957.4 & 3864.9 & 3777.0 & 3692.9 & 3611.6 \\
\hline & Daily & 130.7 & 127.7 & 124.7 & 121.8 & 119.1 & 116.5 \\
\hline \multirow[t]{2}{*}{ August } & Monthly & 3521.1 & 3441.7 & 3362.8 & 3286.9 & 3214.1 & 3144.5 \\
\hline & Daily & 113.6 & 111.0 & 108.5 & 106.0 & 103.7 & 101.4 \\
\hline \multirow[t]{2}{*}{ September } & Monthly & 1329.5 & 1227.5 & 1165.3 & 1160.0 & 1159.4 & 1160.9 \\
\hline & Daily & 44.3 & 40.9 & 38.8 & 38.7 & 38.6 & 38.7 \\
\hline
\end{tabular}


and cooling degree days (CDD) are taken from Turkish State Meteorological Service (TSMS 2017) and belongs to data from 2007 to 2016). In addition, the monthly averages of temperatures (Avg $T_{\text {monthly }}$ ), the differences between minimum and maximum temperatures $\left(\operatorname{Avg}\left(T_{\max }-T_{\min }\right)\right)$, monthly solar radiation $\left(I_{\text {solar }}\right)$ are given in Table 3.

\subsection{1st climate zone: İzmir}

Izmir has Mediterranean climate with hot summers, and cool and rainy winters. It is the third largest city in Turkey and a seaside town. Northern winds prevail in the Gulf during the summer. The melting-solidification behaviour of PCM is simulated between

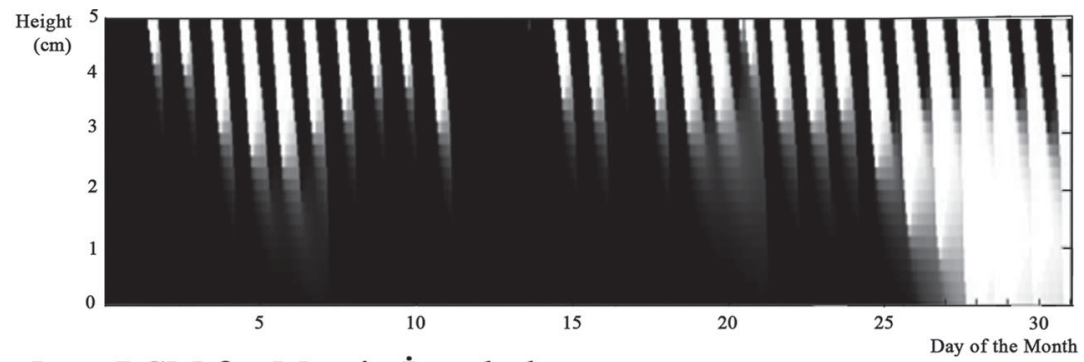

$5 \mathrm{~cm}$ PCM for May in İstanbul

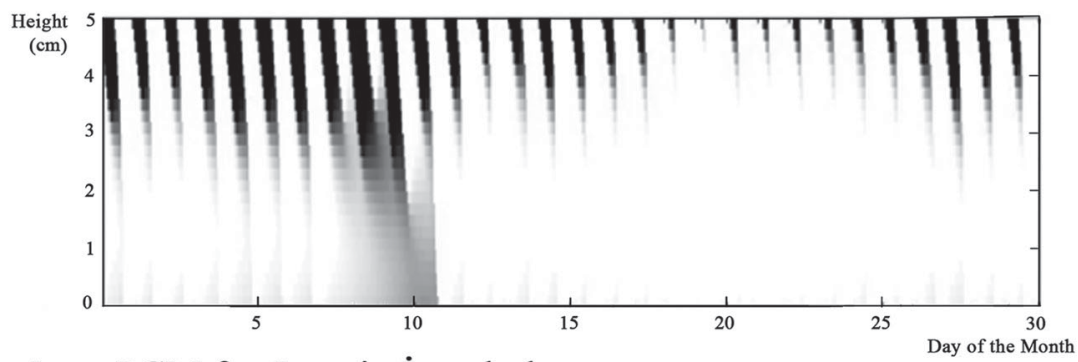

$5 \mathrm{~cm}$ PCM for June in İstanbul

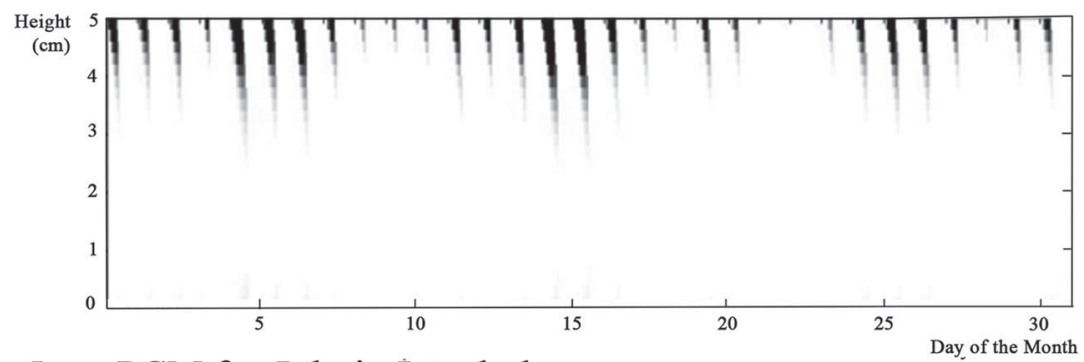

$5 \mathrm{~cm}$ PCM for July in İstanbul

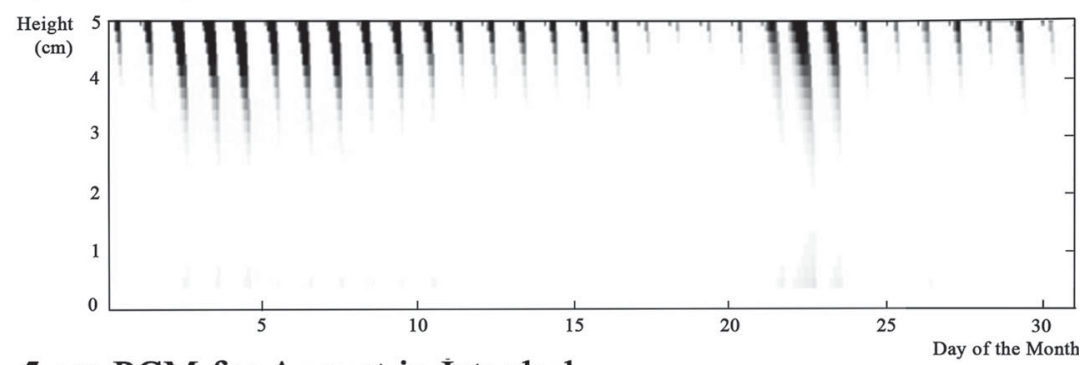

$5 \mathrm{~cm}$ PCM for August in Istanbul

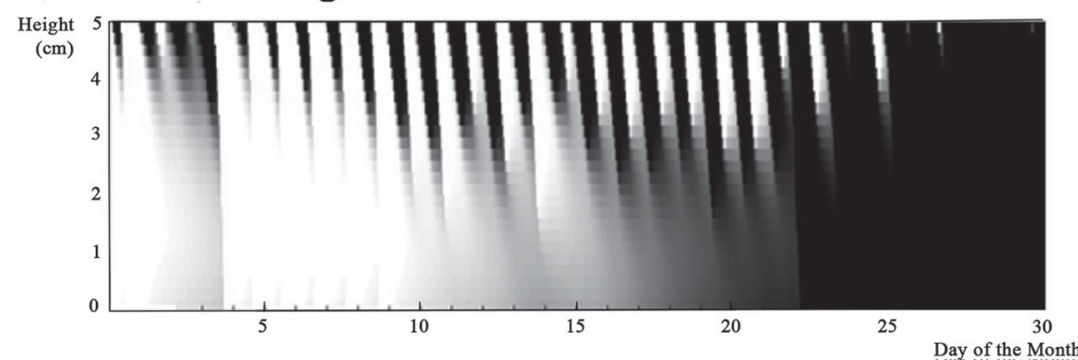

$5 \mathrm{~cm}$ PCM for September in İstanbul

Figure 8. Solid-liquid* states of PCM between June and September in İstanbul (*black denotes solid and white denotes liquid state). 
June and September and is given in Figure 7. The cooling energy required to cool a unit area is given in Table 4 for differing PCM thicknesses.

In May, the PCM changes phase well, especially during the first two-thirds of the month; thus, adding 1, 2, 3, 4 or $5 \mathrm{~cm}$ PCM to the roof decreases the cooling demand by $9.3 \%, 17.5 \%, 27.4 \%$, $38.6 \%$ or $48.2 \%$, respectively. In June, while $1 \mathrm{~cm}$ of PCM continues to change phases, in the latter half of the month, all of the PCM is usually in liquid phase; thus, adding $1,2,3,4$ or $5 \mathrm{~cm}$ PCM to the roof decreases the cooling demand by $3.3 \%, 6.6 \%$, $10.1 \%, 13.0 \%$ or $15.5 \%$, respectively. In the months of June and August, the PCM is mostly in the liquid phase as the outside temperature increases; thus, the decrease in cooling load is not due to latent thermal energy storage. The use of $1 \mathrm{~cm}$ PCM causes $2.3 \%$ and $2.3 \%$, the use of $2 \mathrm{~cm}$ PCM causes $4.6 \%$ and $4.5 \%$, the use of $3 \mathrm{~cm}$ PCM causes $6.8 \%$ and $6.7 \%$, the use of $4 \mathrm{~cm}$ PCM causes $8.9 \%$ and $8.7 \%$, while the use of $5 \mathrm{~cm}$ PCM causes $10.9 \%$ and $10.7 \%$ decreases. In September, the PCM changes phase more effectively as the month progresses, and at the end of the month, more than $2 \mathrm{~cm}$ of PCM continuously changes phase; thus, adding 1, 2, 3, 4 or $5 \mathrm{~cm}$ PCM to the roof decreases the cooling demand by $7.7 \%, 12.4 \%, 12.8 \%, 12.8 \%$ or $12.7 \%$, respectively. Thus, the overall decrease for five months is $3.4 \%, 6.4 \%, 9.0 \%$, $11.4 \%$ or $13.6 \%$ for $1,2,3,4$ or $5 \mathrm{~cm}$ PCM incorporation in the roof element, respectively.

\subsection{2nd climate zone: İstanbul}

İstanbul is the most populated city in Turkey. It has moderate and humid climate; fall, winter and spring are rainy, and while summer is usually warm, winter is cool. Though the climate of Istanbul is mainly Mediterranean, the Sea of Marmara and the Bosphorus cause changes in the climate. During the winter months, the cold-dry air from the Black Sea, the cold and rainy air that comes from the Balkans and the warm and rainy air that come from the Mediterranean all affect the city and arrive one after another. Summer is hot and humid, while the remaining times are rainy. Simulation results for İstanbul are given in Figure 8 and Table 5.

During May, there are days that the PCM does not work, does a complete cycle or works in varying ratios. The inclusion of 1, 2, 3,4 or $5 \mathrm{~cm}$ PCM in the detail decreases the cooling load $17.8 \%$, $36.1 \%, 43.2 \%, 49.7 \%$ or $56.6 \%$, respectively. As the outdoor temperature increases in the months of June, July and August, the PCM is mostly in liquid form. While the required cooling loads increase, the perceived benefits are mostly from the effect of sensible heat storage rather than latent heat storage. The use of $1 \mathrm{~cm}$ PCM causes 5.1\%,2.1\% and $2.1 \%$; the use of $2 \mathrm{~cm}$ PCM causes $8.8 \%, 4.2 \%$ and $4.0 \%$; the use of $3 \mathrm{~cm}$ PCM causes $11.3 \%$, $6.2 \%$ and $5.9 \%$; the use of $4 \mathrm{~cm}$ PCM causes $13.3 \%, 8.1 \%$ and 7.7\%; and the use of $5 \mathrm{~cm}$ PCM causes $15.2 \%, 9.9 \%$ and $9.5 \%$ decreases. In June, July and August, the PCM continues to be mostly in liquid form and thus works little during the first 10 days of September and completes cycling between liquid and solid forms; in other words, it works efficiently in the latter 10 days, and stays mostly in the solid form during the last ten days (Figure 8). Increasing the PCM thickness to more than $2 \mathrm{~cm}$ has a detrimental effect, as observed by the decrease of cooling loads by $11.0 \%, 18.3 \%, 16.6 \%, 13.4 \%$ or $10.8 \%$ with the addition of 1,2 , 3,4 or $5 \mathrm{~cm} \mathrm{PCM}$, respectively. The effect of incorporating 1, 2, 3, 4 or $5 \mathrm{~cm} \mathrm{PCM} \mathrm{into} \mathrm{the} \mathrm{roof} \mathrm{element} \mathrm{for} \mathrm{all} \mathrm{five} \mathrm{months} \mathrm{is} \mathrm{a} 5.0 \%$, $9.3 \%, 11.5 \%, 13.4 \%$ or $15.3 \%$ decrease in the total cooling load, respectively.

\subsection{3rd climate zone: Ankara}

Ankara is the capital and the second most populated city in Turkey. Its dominant climate properties are hot and arid summers and cold winters with low precipitation. Rain averages are low, and the precipitation in winter is mostly snow. Average precipitation and climate characteristics differ between districts. Simulation results for Ankara are given in Figure 9 and Table 6.

PCM is mostly solid in May and September, and the cooling load required during these months is lower than $325 \mathrm{Wh} / \mathrm{m}^{2}$. A $2 \mathrm{~cm}$ PCM thickness is the most effective working thickness; increasing the PCM thickness would bring benefits related to the sensible thermal energy storage in May; however, in September, as the thickness of the PCM increases, its effectiveness decreases. The use of $1 \mathrm{~cm}$ PCM causes $26.6 \%$ and $22.2 \%$, the use of $2 \mathrm{~cm}$ PCM causes $54.0 \%$ and $38.3 \%$, the use of $3 \mathrm{~cm}$ PCM causes $65.1 \%$ and $33.8 \%$, the use of $4 \mathrm{~cm}$ PCM causes $28.2 \%$ and $30.4 \%$, and the use of $5 \mathrm{~cm}$ PCM causes $78.7 \%$ and $25.5 \%$ decreases in the cooling load. In June, there are days when the PCM does not work at all, makes a full charge-decharge cycle, or works in differing amounts. Yet, the utilization of 1,2,3,4 or $5 \mathrm{~cm}$ PCM would bring about a $10.6 \%, 21.8 \%, 26.1 \%, 28.2 \%$ or $31.5 \%$ decrease in cooling energy requirements, respectively. As the outdoor temperatures increase in the months of July and August, the PCM is mostly in liquid form, and the benefits are mostly associated with sensible thermal energy storage rather than latent thermal

Table 5. Monthly and daily average cooling energy requirement in İstanbul $\left(\mathrm{Wh} / \mathrm{m}^{2}\right)$.

\begin{tabular}{|c|c|c|c|c|c|c|c|}
\hline & & No PCM & $\begin{array}{l}1 \mathrm{~cm} \\
\text { PCM }\end{array}$ & $\begin{array}{l}2 \mathrm{~cm} \\
\text { PCM }\end{array}$ & $\begin{array}{l}3 \mathrm{~cm} \\
\text { PCM }\end{array}$ & $\begin{array}{l}4 \mathrm{~cm} \\
\text { PCM }\end{array}$ & $\begin{array}{l}5 \mathrm{~cm} \\
\mathrm{PCM}\end{array}$ \\
\hline \multirow[t]{2}{*}{ May } & Monthly & 835.0 & 686.7 & 533.6 & 474.3 & 419.7 & 362.6 \\
\hline & Daily & 26.9 & 22.2 & 17.2 & 15.3 & 13.5 & 11.7 \\
\hline \multirow[t]{2}{*}{ June } & Monthly & 1927.9 & 1829.2 & 1758.0 & 1710.0 & 1671.8 & 1635.0 \\
\hline & Daily & 64.3 & 61.0 & 58.6 & 57.0 & 55.7 & 54.5 \\
\hline \multirow[t]{2}{*}{ July } & Monthly & 2898.1 & 2838.2 & 2777.1 & 2719.7 & 2664.2 & 2610.7 \\
\hline & Daily & 93.5 & 91.6 & 89.6 & 87.7 & 85.9 & 84.2 \\
\hline \multirow[t]{2}{*}{ August } & Monthly & 2576.6 & 2523.3 & 2473.1 & 2424.7 & 2378.0 & 2333.1 \\
\hline & Daily & 83.1 & 81.4 & 79.8 & 78.2 & 76.7 & 75.3 \\
\hline \multirow{2}{*}{ September } & Monthly & 801.2 & 713.2 & 654.9 & 668.4 & 693.0 & 714.6 \\
\hline & Daily & 26.7 & 23.8 & 21.8 & 22.3 & 23.1 & 23.8 \\
\hline
\end{tabular}




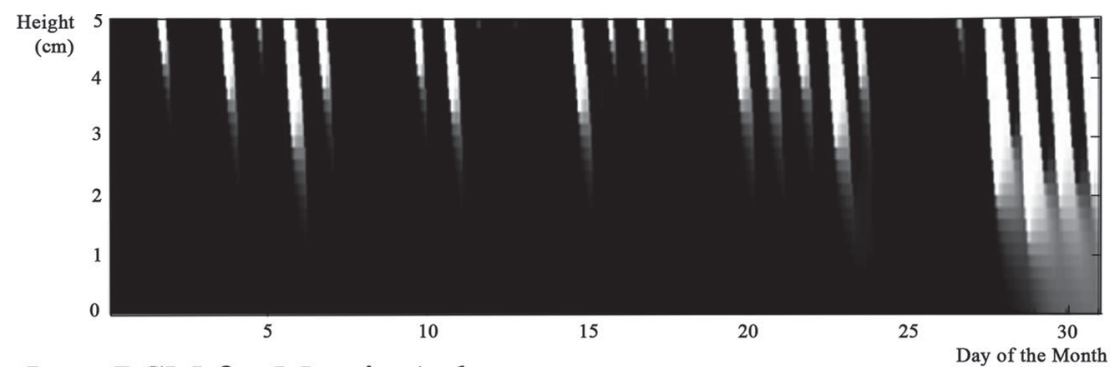

$5 \mathrm{~cm}$ PCM for May in Ankara

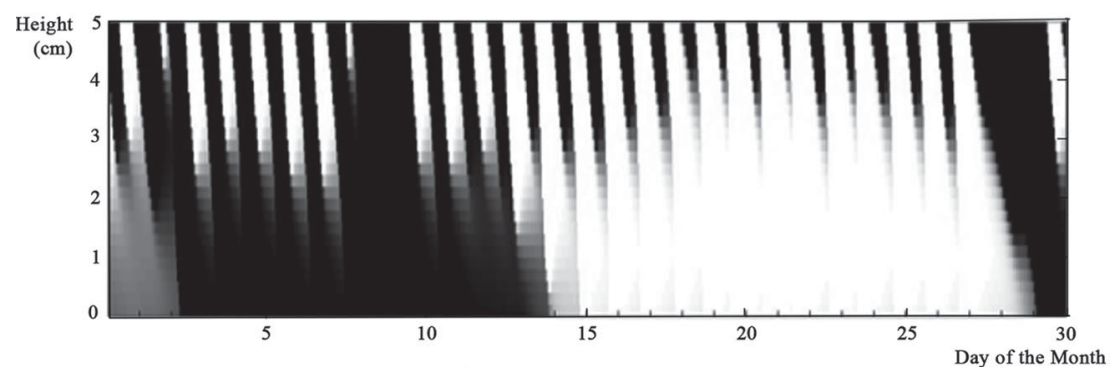

$5 \mathrm{~cm}$ PCM for June in Ankara

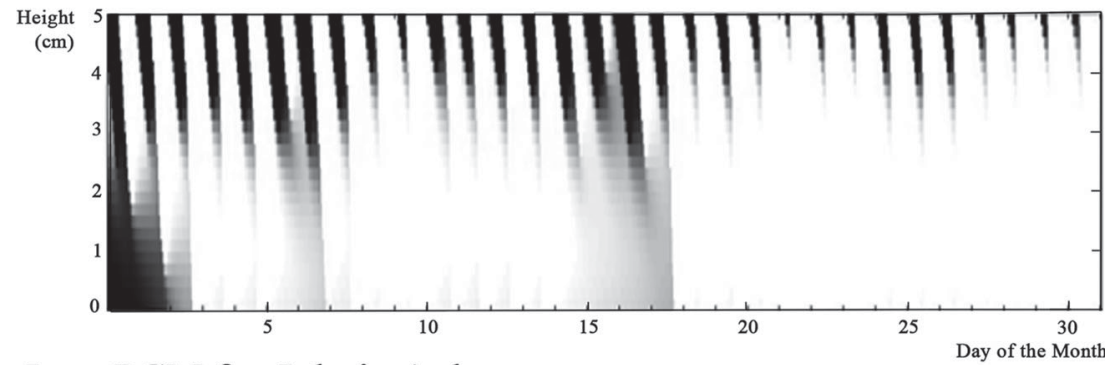

$5 \mathrm{~cm}$ PCM for July in Ankara

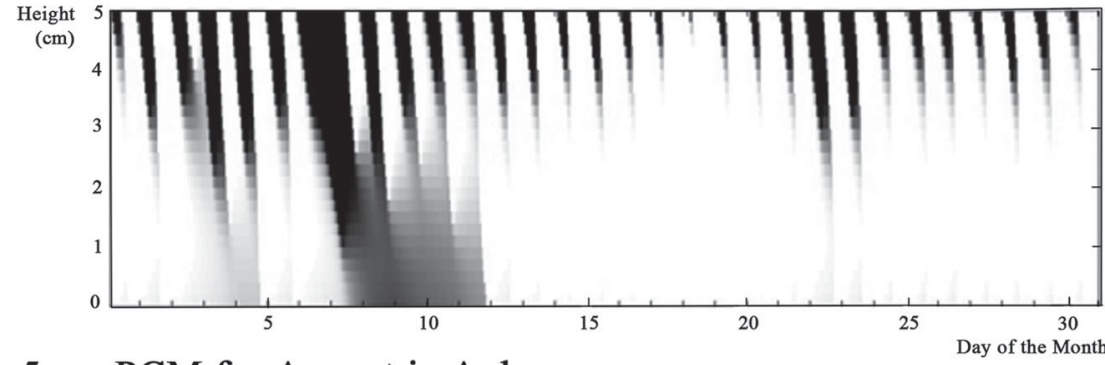

$5 \mathrm{~cm}$ PCM for August in Ankara

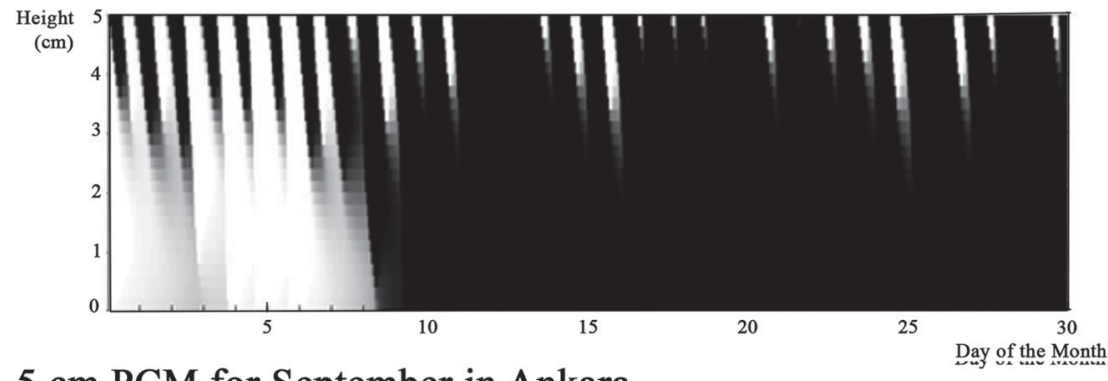

$5 \mathrm{~cm}$ PCM for September in Ankara

Figure 9. Solid-liquid* states of PCM between June and September in Ankara (*black denotes solid and white denotes liquid state).

energy storage. The cooling load increases in July and August, and the use of $1 \mathrm{~cm}$ PCM causes $4.7 \%$ and $4.5 \%$, the use of $2 \mathrm{~cm}$ PCM causes $8.0 \%$ and $8.2 \%$, the use of $3 \mathrm{~cm}$ PCM causes $11.1 \%$ and $11.2 \%$, the use of $4 \mathrm{~cm}$ PCM causes $14.6 \%$ and $13.4 \%$, and the use of $5 \mathrm{~cm}$ PCM causes $18.1 \%$ and $14.7 \%$ decreases. All five months correspond to an overall decrease of $8.4 \%, 15.9 \%, 19.3 \%$, $22.1 \%$ or $24.3 \%$ for $1,2,3,4$ or $5 \mathrm{~cm}$ PCM incorporation in the roof element, respectively. 
Table 6. Monthly and daily average cooling energy requirement in Ankara $\left(\mathrm{Wh} / \mathrm{m}^{2}\right)$.

\begin{tabular}{|c|c|c|c|c|c|c|c|}
\hline & & No PCM & $\begin{array}{l}1 \mathrm{~cm} \\
\text { PCM }\end{array}$ & $\begin{array}{l}2 \mathrm{~cm} \\
P C M\end{array}$ & $\begin{array}{l}3 \mathrm{~cm} \\
\text { PCM }\end{array}$ & $\begin{array}{l}4 \mathrm{~cm} \\
\text { PCM }\end{array}$ & $\begin{array}{l}5 \mathrm{~cm} \\
P C M\end{array}$ \\
\hline \multirow[t]{2}{*}{ May } & Monthly & 323.2 & 237.4 & 148.8 & 112.9 & 79.7 & 68.8 \\
\hline & Daily & 10.4 & 7.7 & 4.8 & 3.6 & 2.6 & 2.2 \\
\hline \multirow[t]{2}{*}{ June } & Monthly & 970.3 & 867.2 & 759.3 & 717.4 & 696.4 & 664.7 \\
\hline & Daily & 32.3 & 28.9 & 25.3 & 23.9 & 23.2 & 22.2 \\
\hline \multirow[t]{2}{*}{ July } & Monthly & 1693.0 & 1613.8 & 1557.3 & 1505.2 & 1445.9 & 1387.0 \\
\hline & Daily & 54.6 & 52.1 & 50.2 & 48.6 & 46.6 & 44.7 \\
\hline \multirow[t]{2}{*}{ August } & Monthly & 1493.5 & 1426.4 & 1371.1 & 1326.9 & 1293.7 & 1274.6 \\
\hline & Daily & 48.2 & 46.0 & 44.2 & 42.8 & 41.7 & 41.1 \\
\hline \multirow[t]{2}{*}{ September } & Monthly & 310.9 & 241.9 & 191.8 & 205.9 & 216.4 & 231.6 \\
\hline & Daily & 10.4 & 8.1 & 6.4 & 6.9 & 7.2 & 7.7 \\
\hline
\end{tabular}

\subsection{4th climate zone: Erzurum}

Erzurum is one of the highest elevated and coldest cities in Turkey. Its climate is severe, with cold and snowy winters and mild and dry summers. Erzurum is covered with snow for 150 days of the year. The simulation results for Erzurum are given in Figure 10 and Table 7.

In the months of May and September, the PCM is mostly in the solid phase. The cooling required without PCM is low, and the addition of 4 or $5 \mathrm{~cm}$ PCM decreases it further, lower than $1 \mathrm{Wh} / \mathrm{m}^{2}$ for May and $25 \mathrm{Wh} / \mathrm{m}^{2}$ for September. The decrease rate is $52.3 \%$ and $33.9 \%$ for $1 \mathrm{~cm}, 95.8 \%$ and $76.7 \%$ for $2 \mathrm{~cm}$, $98.8 \%$ and $86.5 \%$ for $3 \mathrm{~cm}, 98.8 \%$ and $87.8 \%$ for $4 \mathrm{~cm}, 99.1 \%$ and $88.4 \%$ for $5 \mathrm{~cm}$ in May and September, respectively. In June, PCM works in differing amounts; while the most efficient PCM thickness is $3 \mathrm{~cm}$, the incorporation of 4 or $5 \mathrm{~cm}$ also has added sensible heat effects; $1,2,3,4$ or $5 \mathrm{~cm}$ PCM incorporation decreases cooling load by $24.9 \%, 55.9 \%, 68.4 \%, 73.1 \%$ or $75.3 \%$, respectively. In the months of July and August, the melting-solidification cycle is intermittent. Use of $1 \mathrm{~cm}$ PCM causes $16.0 \%$ and $15.8 \%$, use of $2 \mathrm{~cm}$ PCM causes $32.0 \%$ and $32.1 \%$, use of $3 \mathrm{~cm}$ PCM causes $42.1 \%$ and $34.8 \%$, use of $4 \mathrm{~cm}$ PCM causes $52.6 \%$ and $37.3 \%$, and use of $5 \mathrm{~cm}$ PCM causes $58.4 \%$ and $39.4 \%$ decreases in the cooling load. The effect of incorporating 1, 2, 3, 4 or $5 \mathrm{~cm}$ PCM into the roof element for all five months is a $20.1 \%$, $41.5 \%, 49.2 \%, 54.9 \%$ or $58.3 \%$ decrease in the total cooling load, respectively.

\section{Discussion}

Monthly simulation results showing energy performance of a roof with differing amounts of PCM from May to September are summarized in Figures 11-15 for İzmir, representing the 1st climate zone, İstanbul, representing the 2nd climate zone, Ankara, representing the 3 rd climate zone, and Erzurum, representing the 4th climate zone of Turkey. There are similarities between the melting-solidification cycle of PCM in all of the climate zones. In summer conditions, after a few hot summer days, the thermal energy stored in the liquid phase of PCM cannot be given to the surroundings, and the melting-solidification cycle does not take place in the whole PCM. Thus, sensible thermal heat capacity is dominant in the months of June (Figure 12), July (Figure 13) and August (Figure 14). However, during transitional seasons, as in May (Figure 11) and September (Figure 15), solar energy is more efficiently stored as latent thermal energy; consequently, the required cooling energy decreases accordingly.
Kong et al. (2014) studied the placement of PCM on the outer or inner side of the roof slab and building walls by simulations for Tianjin, China. They found placement on the inner side would be more beneficial for retrofits. Pasupathy et al. (2008) placed the PCM on the outer side of the slab for experimental and numerical study in Chennai City, India, and found it suitable for the climate. The PCM is also placed on the outer side of the slab in this case and the results are given accordingly. The results show that the damping effect of a roof with PCM is better than a roof without PCM; thus, when the amount of PCM increases, the thermal inertia of the roof also increases. Yet, while the PCM absorbs solar energy during the day, the main energy damping takes place in the heat insulation material, therefore the placement of the PCM below the thermal insulation material would improve results.

The charging-discharging cycle of PCM requires variation between day and night temperatures, the PCM was expected to change phase and reduce the required cooling load more so in arid climates, yet the results show more reduction potential in cities with humid climates. The main reason for this is because the aforementioned cities are hotter and require more energy to cool; therefore, although the PCM worked for more hours, reductions were less in the overall results since the load was also lesser.

\section{Conclusion}

PCM containing building elements can be incorporated into any part of the building; however, since the heat transfer between indoors and outdoors mainly takes place via the building envelope, this study examined the properties of a roof element containing PCM. One of the reasons for the selection of a roof element is to have solar exposure irrespective of orientation; therefore, having a more homogenous behaviour under climate conditions simplifies the problem of comparison between the cases. Another reason is that roofs play a significant role in energy transmission since they are exposed to the elements all day long, especially solar radiation during the summer. In addition, the facades need to be flexible according to architectural requirements, while the roof is more stationary, therefore the roof would be a good place to place more thermal energy storage capacity.

This is a parametric study under different climate zones and for different PCM thicknesses, therefore, the results created a complex mosaic for interpretation. The results from the case show that both the characteristics of the climatic zone and 


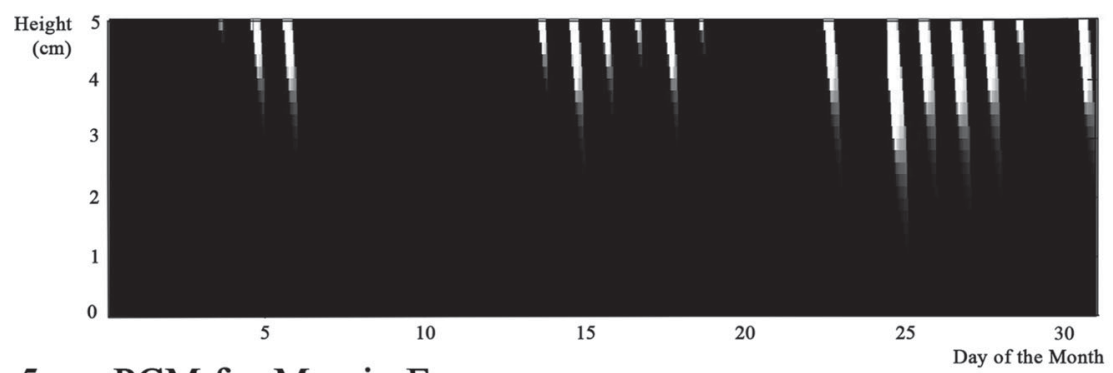

$5 \mathrm{~cm}$ PCM for May in Erzurum

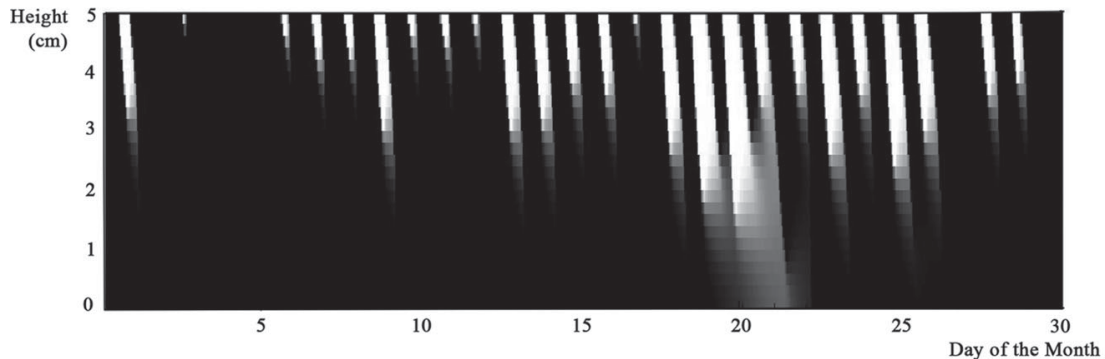

$5 \mathrm{~cm}$ PCM for June in Erzurum

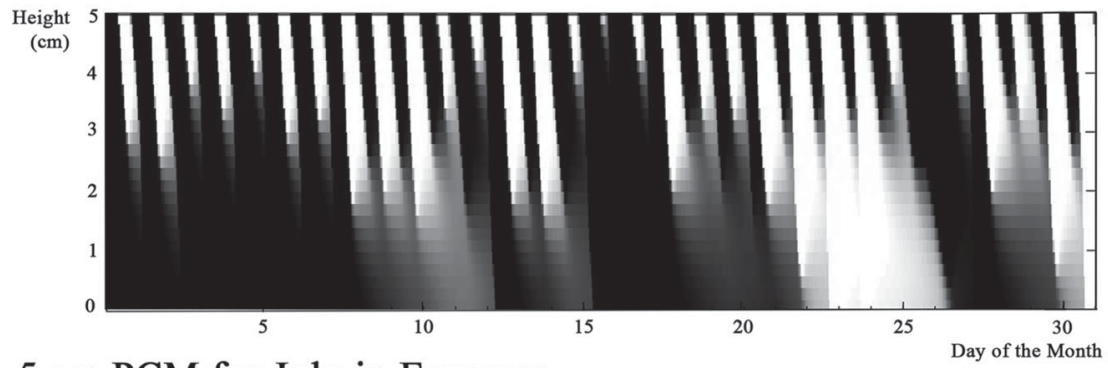

$5 \mathrm{~cm}$ PCM for July in Erzurum

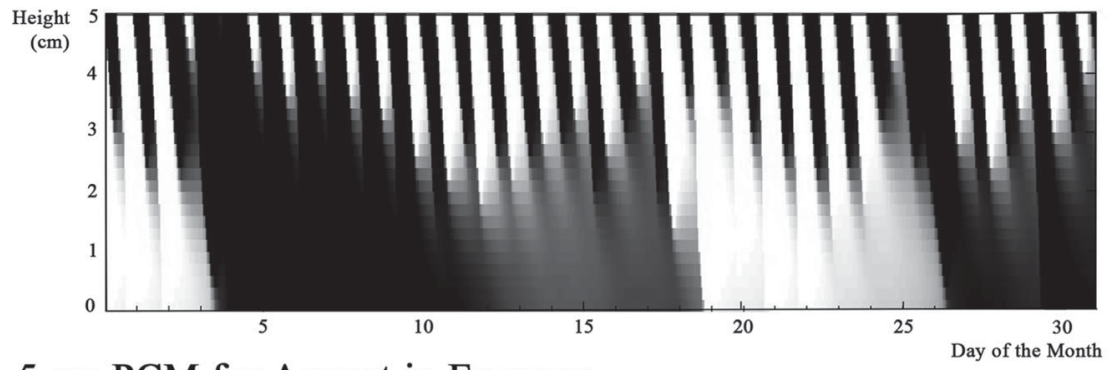

$5 \mathrm{~cm}$ PCM for August in Erzurum

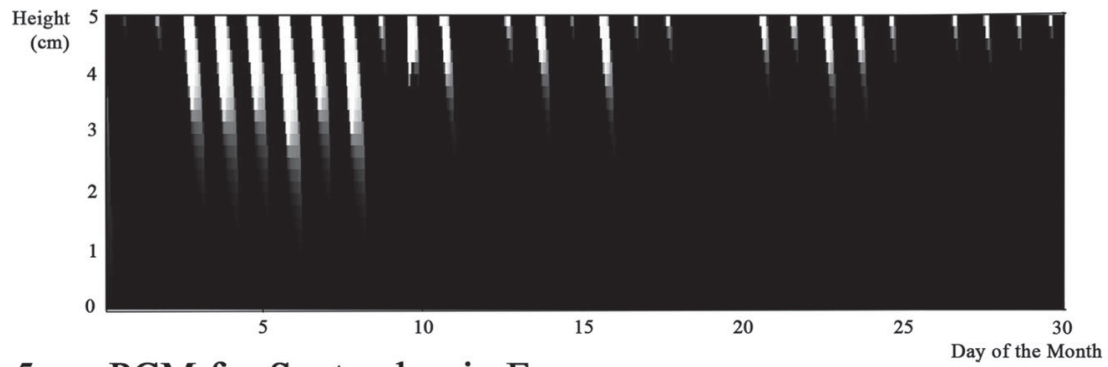

$5 \mathrm{~cm}$ PCM for September in Erzurum

Figure 10. Solid-liquid* states of PCM between June and September in Erzurum (*black denotes solid and white denotes liquid state).

the microclimatic characteristics of the building site need to be taken into account during PCM selection. The PCM used in this study was more successful during the transitional months, however one type of PCM cannot succeed under every type of weather as in a climate with four seasons, hence, the use of more than one type of PCM, or PCMs with more than one melting/freezing point, should be considered for the building element. While the latent heat storage capacity of PCM is related to the amount of PCM; yet, when all of the PCM changes phase, the storage capacity reaches the maximum available latent thermal energy storage capacity, and heat is only stored sensibly, therefore the thickness for PCM should be optimized before 
Table 7. Monthly and daily average cooling energy requirement in Erzurum $\left(\mathrm{Wh} / \mathrm{m}^{2}\right)$.

\begin{tabular}{|c|c|c|c|c|c|c|c|}
\hline & & No PCM & $\begin{array}{l}1 \mathrm{~cm} \\
\text { PCM }\end{array}$ & $\begin{array}{l}2 \mathrm{~cm} \\
\text { PCM }\end{array}$ & $\begin{array}{l}3 \mathrm{~cm} \\
\text { PCM }\end{array}$ & $\begin{array}{l}4 \mathrm{~cm} \\
\text { PCM }\end{array}$ & $\begin{array}{l}5 \mathrm{~cm} \\
\text { PCM }\end{array}$ \\
\hline \multirow[t]{2}{*}{ May } & Monthly & 74.7 & 35.6 & 3.2 & 1.4 & 0.9 & 0.9 \\
\hline & Daily & 2.4 & 1.1 & 0.1 & 0.0 & 0.0 & 0.0 \\
\hline \multirow[t]{2}{*}{ June } & Monthly & 306.4 & 230.0 & 135.0 & 96.9 & 82.3 & 75.7 \\
\hline & Daily & 10.2 & 7.7 & 4.5 & 3.2 & 2.7 & 2.5 \\
\hline \multirow[t]{2}{*}{ July } & Monthly & 706.7 & 593.5 & 480.9 & 409.5 & 335.3 & 294.1 \\
\hline & Daily & 22.8 & 19.1 & 15.5 & 13.2 & 10.8 & 9.5 \\
\hline \multirow[t]{2}{*}{ August } & Monthly & 635.7 & 535.0 & 431.7 & 414.3 & 398.6 & 385.2 \\
\hline & Daily & 20.5 & 17.3 & 13.9 & 13.4 & 12.9 & 12.4 \\
\hline \multirow[t]{2}{*}{ September } & Monthly & 122.7 & 81.2 & 28.7 & 16.6 & 15.0 & 14.3 \\
\hline & Daily & 4.1 & 2.7 & 1.0 & 0.6 & 0.5 & 0.5 \\
\hline
\end{tabular}

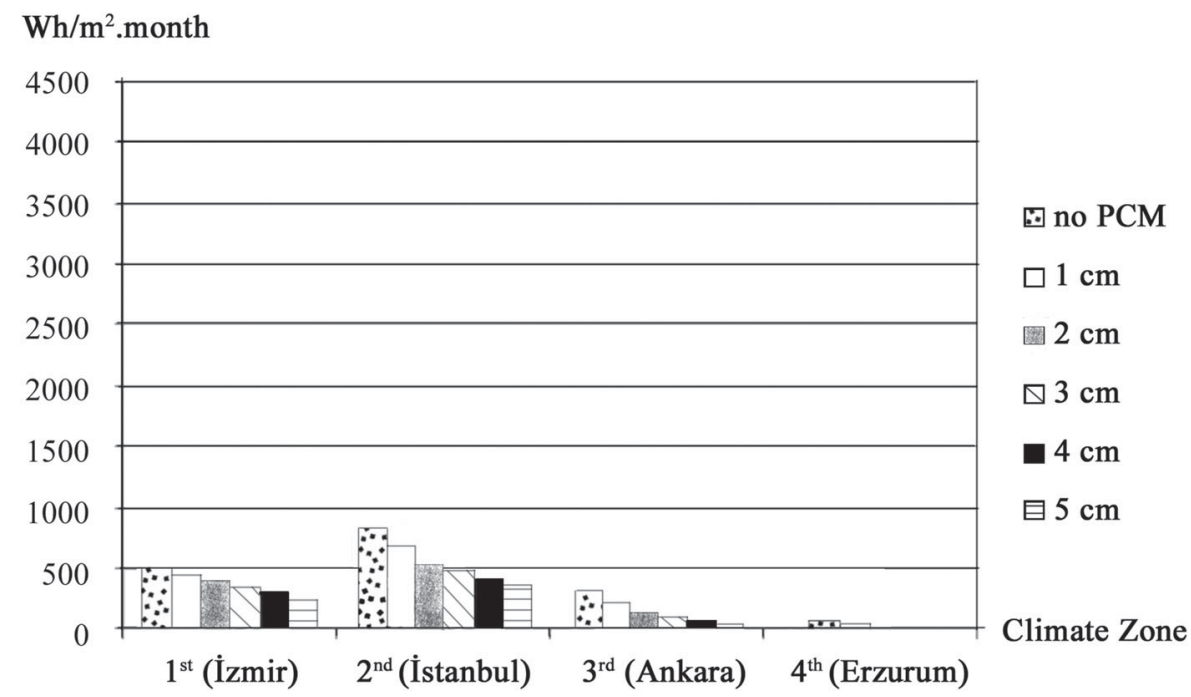

Figure 11. Cooling loads for May per unit surface area.

application. Another implication from the case is that better performance would be possible by either night ventilation or placing PCM under the thermal insulation layer.

This paper proposed a methodology to evaluate the integration of PCM, and thus latent thermal energy storage, in the building envelope. The results from the case show that the model is flexible and can be utilized to evaluate the effect of various parameters inside a building element under differing climatic conditions. Possible studies include the following; various building elements and detailing, configurations of PCM placement, the investigation of optimum PCMs under different weather conditions, properties of covering materials, solar

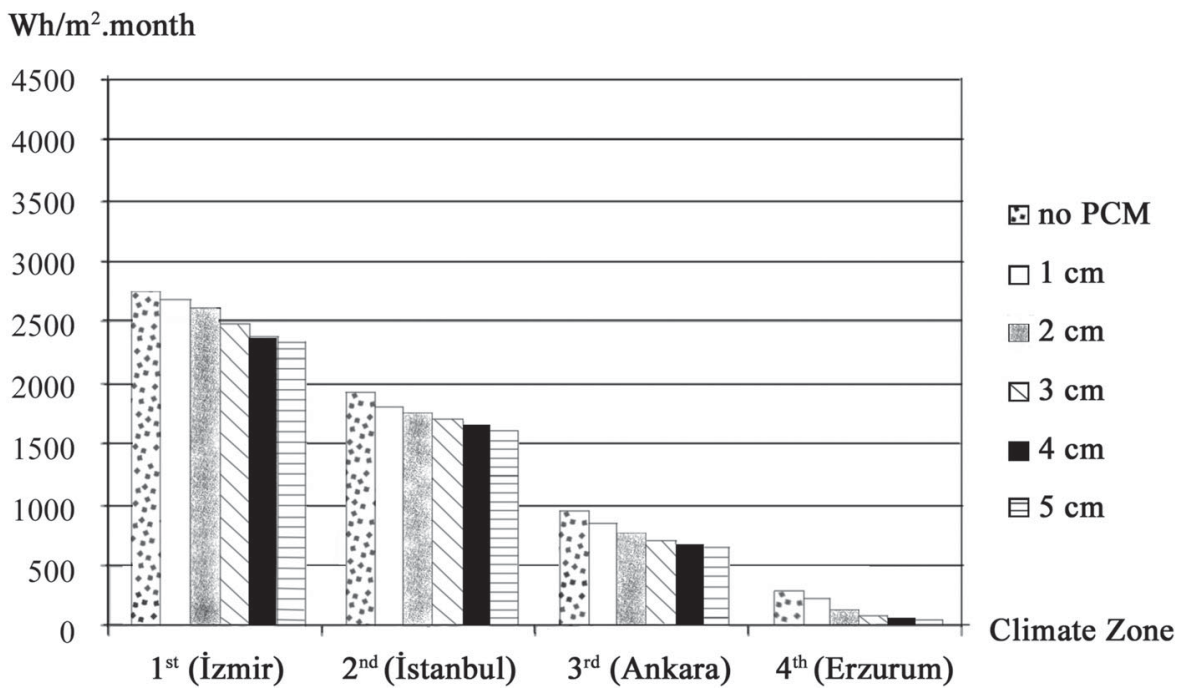

Figure 12. Cooling loads for June per unit surface area. 


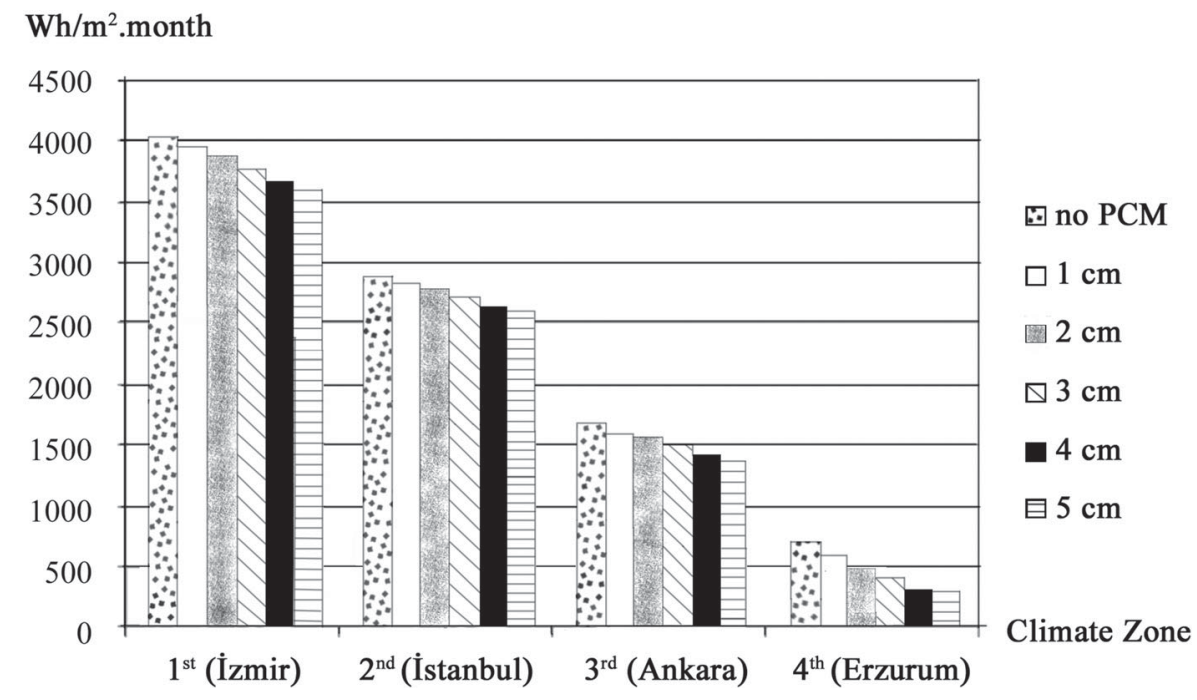

Figure 13. Cooling loads for July per unit surface area.

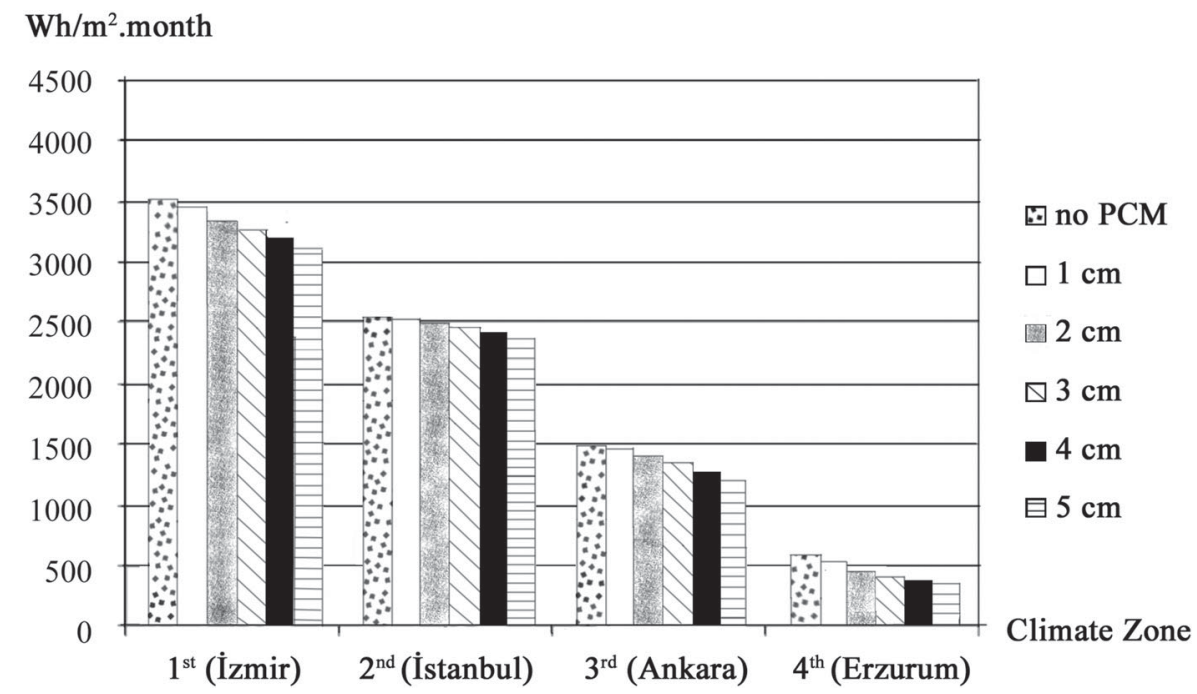

Figure 14. Cooling loads for August per unit surface area.

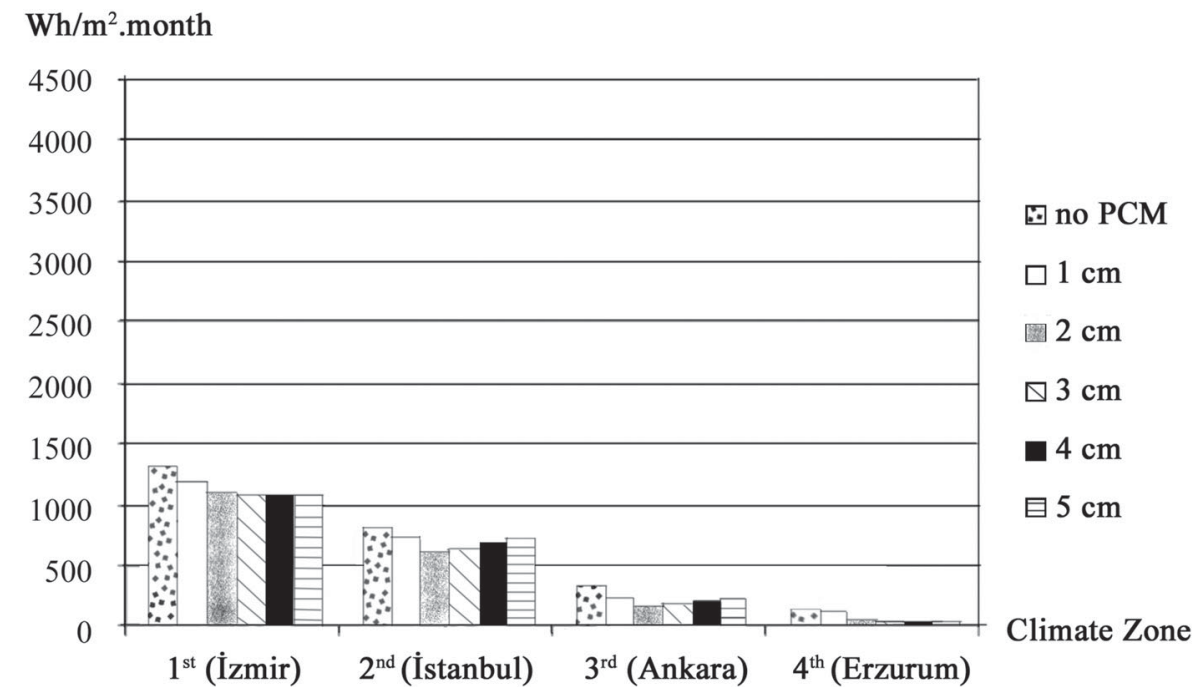

Figure 15. Cooling loads for September per unit surface area. 
orientation, shading, different indoor temperatures, various climatic conditions and night cooling.

\section{Acknowledgements}

The authors would like to thank Professor Dr H. Çetin Türkçü for his valuable contributions in the beginning phase of this comprehensive study.

\section{Disclosure statement}

No potential conflict of interest was reported by the authors.

\section{Funding}

This work was supported by Dokuz Eylül Üniversitesi under Grant number 2010.KB.FEN.011.

\section{References}

Akeiber, Hussein, Payam Nejat, Muhd Zaimi Abd Majid, Mazlan A. Wahid, Fatemeh Jomehzadeh, Iman Zeynali Famileh, John Kaiser Calautit, Ben Richard Hughes, and Sheikh Ahmad Zaki. 2016. "A Review on Phase Change Material (PCM) for Sustainable Passive Cooling in Building Envelopes." Renewable and Sustainable Energy Reviews 60: 1470-1497.

Alqallaf, Hashem J., and Esam M. Alawadhi. 2013. "Concrete Roof with Cylindrical Holes Containing PCM to Reduce the Heat Gain." Energy and Buildings 61: 73-80.

ANSYS Inc. 2009. ANSYS FLUENT 12.0 Theory Guide.

Başaran, Tahsin. 2011. "Thermal Analysis of the Domed Vernacular Houses of Harran, Turkey." Indoor and Built Environment 20 (5): 543-554.

Cengel, Yunus A. 2007. Heat and Mass Transfer: A Practical Approach. 3rd ed. Boston: McGraw-Hill.

Chung, T. J. 2002. Computational Fluid Mechanics. Cambridge: Cambridge University Press.

Duffie, John A., and William A. Beckman. 1991. Solar Engineering of Thermal Processes. New York: Wiley.

Ezan, Mehmet Akif, and Aytunc Erek. 2012. "Solidification and Melting Periods of an Ice-on-Coil Latent Heat Thermal Energy Storage System." Journal of Heat Transfer 134 (6): 062301.

Ezan, Mehmet Akif, Aytunç Erek, and Ibrahim Dincer. 2011. "Energy and Exergy Analyses of an Ice-on-Coil Thermal Energy Storage System." Energy 36 (11): 6375-6386.

Ghoreishi, Amir H., and Mir M. Ali. 2013. "Parametric Study of Thermal Mass Property of Concrete Buildings in US Climate Zones." Architectural Science Review 56 (2): 103-117.

Hyde, R. A., K. Yeang, N. Groenhout, F. Barram, M. Webster-Mannison, K. Healey, and E. Halawa. 2009. "Exploring Synergies with Innovative Green Technologies for Advanced Renovation Using a Bioclimatic Approach." Architectural Science Review 52 (3): 229-236.

Jin, Xing, Shuanglong Zhang, Xiaodong Xu, and Xiaosong Zhang. 2014 "Effects of PCM State on its Phase Change Performance and the Thermal Performance of Building Walls." Building and Environment 81: 334-339.

Kalnæs, Simen Edsjø, and Bjørn Petter Jelle. 2015. "Phase Change Materials and Products for Building Applications: A State-of-the-Art Review and Future Research Opportunities." Energy and Buildings 94: 150-176.

Kauranen, P., K. Peippo, and P. D. Lund. 1991. "An Organic PCM Storage System with Adjustable Melting Temperature." Solar Energy 46 (5): 275-278.

Kong, Xiangfei, Shilei Lu, Yiran Li, Jingyu Huang, and Shangbao Liu. 2014. "Numerical Study on the Thermal Performance of Building Wall and Roof Incorporating Phase Change Material Panel for Passive Cooling Application." Energy and Buildings 81: 404-415.

Li, Dong, Yumeng Zheng, Changyu Liu, and Guozhong Wu. 2015. "Numerical Analysis on Thermal Performance of Roof Contained PCM of a
Single Residential Building." Energy Conversion and Management 100: 147-156.

Liu, C., Y. Zhou, D. Li, F. Meng, Y. Zheng, and X. Liu. 2016. "Numerical Analysis on Thermal Performance of a PCM-Filled Double Glazing Roof." Energy and Buildings 125: 267-275.

Lu, Shilei, Yafei Chen, Shangbao Liu, and Xiangfei Kong. 2016. “Experimental Research on a Novel Energy Efficiency Roof Coupled with PCM and Cool Materials." Energy and Buildings 127: 159-169.

Meteonorm. 2012. METEONORM: Global Meteorological Database for Solar Energy and Applied Climatology. http://www.meteonorm.com

Mithraratne, Kumar, and Brenda Vale. 2006. "Simulation of High Thermal Mass Passive Solar Buildings." Architectural Science Review 49 (1): 17-29.

Navarro, Lidia, Alvaro de Gracia, Dervilla Niall, Albert Castell, Maria Browne, Sarah J. McCormack, Philip Griffiths, and Luisa F. Cabeza. 2016. "Thermal Energy Storage in Building Integrated Thermal Systems: A Review. Part 2. Integration as Passive System." Renewable Energy 85: 1334-1356.

Pasupathy, A., L. Athanasius, R. Velraj, and R. V. Seeniraj. 2008. "Experimental Investigation and Numerical Simulation Analysis on the Thermal Performance of a Building Roof Incorporating Phase Change Material (PCM) for Thermal Management." Applied Thermal Engineering 28 (5): 556-565.

Remund, Jan, and Stefan C. Müller. 2011. "Solar Radiation and Uncertainty Information of Meteonorm 7." Proceedings of 26th European Photovoltaic Solar Energy Conference and Exhibition.

Senel Solmaz, Aslihan, Fahriye H. Halicioglu, and Suat Gunhan. 2016. "An Approach for Making Optimal Decisions in Building Energy Efficiency Retrofit Projects." Indoor and Built Environment. doi:10.1177/1420326X 16674764

Sheth Karathia, Falguni. 2011. Analysis of Thermal Properties of Phase Change Materials (PCM) Using Differential Scanning Calorimeter (DSC). Lleida, Spain: Universitat de Lleida.

Slee, Ben, Tom Parkinson, and Richard Hyde. 2014. "Quantifying Useful Thermal Mass: How Much Thermal Mass do you Need?" Architectural Science Review 57 (4): 271-285.

Soares, N., J. J. Costa, A. R. Gaspar, and P. Santos. 2013. "Review of Passive PCM Latent Heat Thermal Energy Storage Systems towards Buildings' Energy Efficiency." Energy and Buildings 59: 82-103.

Souayfane, Farah, Farouk Fardoun, and Pascal-Henry Biwole. 2016. "Phase Change Materials (PCM) for Cooling Applications in Buildings: A Review." Energy and Buildings 129: 396-431.

Szokolay, S. V. 2004. Introduction to Architectural Science: the basic of Sustainable Design. Burlington, MA: Architectural Press.

Tokuç, Ayça. 2013. “Faz değişim malzemelerinin ısıl enerji depolama amacıyla yapı elemanlarında kullanılması (Use of Phase Change Materials in Building Elements for Thermal Energy storage, in Turkish)." PhD diss., Dokuz Eylül University.

Tokuç, Ayça, Tahsin Başaran, and S. Cengiz Yesügey. 2015a. "An Experimental and Numerical Investigation on the Use of Phase Change Materials in Building Elements: The Case of a Flat Roof in Istanbul." Energy and Buildings 102: 91-104.

Tokuç, Ayça, Tahsin Başaran, and S. Cengiz Yesügey. 2015b. "Experimental Data Showing the Thermal Behavior of a Flat Roof with Phase Change Material." Data in Brief 5: 476-480.

Tokuç, Ayça, Tahsin Başaran, and S. Cengiz Yesügey. 2015c. "Effect of Thermal Energy Storage in a Flat Roof in Mediterranean Climate." The 13th International Conference on Energy Storage: Greenstock.

Turkish Standards Institute. 2008. "825 (TS 825), 2008." Official Gazette 27019.

Turkish State Meteorological Service. 2012. Average climate data for İzmir between 2000 and 2010.

Turkish State Meteorological Service. 2017. https://www.mgm.gov.tr.

Versteeg, Henk Kaarle, and Weeratunge Malalasekera. 2007. An Introduction to Computational Fluid Dynamics: the Finite Volume Method. Harlow, England: Pearson Education.

Yang, Liu, Haiyan Yan, and Joseph C. Lam. 2014. "Thermal Comfort and Building Energy Consumption Implications - A Review." Applied Energy 115: 164-173. 
